\title{
The Atherogenic Lipoprotein Lp(a) is Internalized and Degraded in a Process Mediated by the VLDL Receptor
}

\author{
Kelley McTigue Argraves, ${ }^{\star}$ Karen F. Kozarsky, ${ }^{\ddagger}$ John T. Fallon, ${ }^{\S}$ Peter C. Harpel, ${ }^{\|}$and Dudley K. Strickland ${ }^{\star}$ \\ *Department of Biochemistry, Holland Laboratory, American Red Cross, Rockville, Maryland 20855; ${ }^{*}$ Institute of Human Gene Therapy \\ and Department of Molecular and Cellular Engineering, University of Pennsylvania, Philadelphia, Pennsylvania 19104; and ${ }^{\S}$ The \\ Cardiovascular Institute and Departments of Pathology and Medicine and the ${ }^{\|}$Division of Hematology, Department of Medicine, \\ The Mount Sinai School of Medicine, New York, New York 10029
}

\begin{abstract}
$\mathrm{Lp}(\mathrm{a})$ is a major inherited risk factor associated with premature heart disease and stroke. The mechanism of $\mathrm{Lp}(\mathrm{a})$ atherogenicity has not been elucidated, but likely involves both its ability to influence plasminogen activation as well as its atherogenic potential as a lipoprotein particle after receptor-mediated uptake. We demonstrate that fibroblasts expressing the human VLDL receptor can mediate endocytosis of $\mathrm{Lp}(\mathrm{a})$, leading to its degradation within lysosomes. In contrast, fibroblasts deficient in this receptor are not effective in catabolizing $\operatorname{Lp}(\mathrm{a})$. $\operatorname{Lp}(\mathrm{a})$ degradation was prevented by antibodies against the VLDL receptor, and by RAP, an antagonist of ligand binding to the VLDL receptor. Catabolism of $\mathrm{Lp}(\mathrm{a})$ was inhibited by apolipoprotein(a), but not by LDL or by monoclonal antibodies against apoB100 that block LDL binding to the LDL receptor, indicating that apolipoprotein(a) mediates $L p(a)$ binding to this receptor. Removal of $\mathrm{Lp}(\mathrm{a})$ antigen from the mouse circulation was delayed in mice deficient in the VLDL receptor when compared with control mice, indicating that the VLDL receptor may play an important role in $\mathrm{Lp}(\mathrm{a})$ catabolism in vivo. We also demonstrate the expression of the VLDL receptor in macrophages present in human atherosclerotic lesions. The ability of the VLDL receptor to mediate endocytosis of $\mathrm{Lp}$ (a) could lead to cellular accumulation of lipid within macrophages, and may represent a molecular basis for the atherogenic effects of Lp(a). (J. Clin. Invest. 1997. 100:21702181.) Key words: adenovirus • atherosclerosis • macrophage • endothelium • endocytosis
\end{abstract}

\section{Introduction}

The lipoprotein $\mathrm{Lp}(\mathrm{a})$ has been identified as a major risk factor for atherosclerosis (1-3). This lipoprotein is distinguished from LDL by the presence of apolipoprotein(a) (apo[a]),

Address correspondence to Dudley K. Strickland, Department of Biochemistry, American Red Cross, 15601 Crabbs Branch Way, Rockville, MD 20855. Phone: 301-738-0726; FAX: 301-738-0794; E-mail: strickla@usa.redcross.org; or to Peter C. Harpel, Department of Medicine, Mount Sinai Medical Center, One Gustave L. Levy Place, New York, NY 10029-6574. Phone: 212-241-0546; FAX: 212-996-1029; E-mail: pharpel@smtplink.mssm.edu

Received for publication 12 April 1997 and accepted in revised form 3 September 1997.

J. Clin. Invest.

(C) The American Society for Clinical Investigation, Inc. 0021-9738/97/11/2170/12 \$2.00

Volume 100, Number 9, November 1997, 2170-2181

http://www.jci.org which contains multiple copies of domains closely related to the fourth kringle of plasminogen, one domain related to the fifth kringle of plasminogen, and a region similar to the proteinase domain of plasminogen (4). Studies have identified apo(a) alleles encoding proteins containing from 12 to 51 type four kringle repeats (K4) (5). The high degree of size polymorphism in the apo(a) gene is thought to be responsible for the wide range of plasma concentrations of $\mathrm{Lp}(\mathrm{a})$ found in different individuals (6).

The mechanisms of $\mathrm{Lp}(\mathrm{a})$ atherogenicity, however, have not been elucidated; Lp(a)'s unique structural features suggest that this lipoprotein has both thrombogenic and atherogenic potentials. $\mathrm{Lp}(\mathrm{a})$ associates with the vessel wall and inhibits binding of plasminogen to the cell surface $(7,8)$. This association reduces the extent of plasmin generation, thereby interfering with clot lysis. Inhibition of cell surface plasminogen activation by $\operatorname{Lp}(\mathrm{a})$ also reduces the production of TGF- $\beta$ (9), a molecule that prevents smooth muscle cell proliferation. This inhibition likely represents an important in vivo activity of Lp(a), since transgenic mice expressing human apo(a) are not only more susceptible than control mice to the development of lipid-staining lesions in the aorta (10), but they also show a decreased activation of plasminogen and TGF- $\beta$ in the aortic wall (11).

While the physiological role of $\mathrm{Lp}(\mathrm{a})$ is not known, it has been speculated to deliver cholesterol to cells at wound sites (12), a function that may become pathological when plasma levels of $\mathrm{Lp}(\mathrm{a})$ are high. Efficient delivery of cholesterol to cells requires the presence of cell surface receptors to mediate lipoprotein endocytosis (13); the identity of endocytic receptors responsible for the uptake of $\mathrm{Lp}(\mathrm{a})$ is a topic of current debate. $\mathrm{Lp}(\mathrm{a})$ has been observed to bind to the LDL receptor, and like LDL, it is removed more rapidly from plasma of mice in which the LDL receptor has been overexpressed in the liver (14). These experiments indicate that the LDL receptor can mediate cellular catabolism of Lp(a). Catabolism of ${ }^{125} \mathrm{I}-\mathrm{Lp}(\mathrm{a})$, however, is not significantly different in patients with homozygous familial hypercholesterolemia who lack functional LDL receptors when compared to their heterozygous parents or individuals with normal levels of functional LDL receptors (15). Furthermore, drugs that increase LDL receptor activity do not appear to lower Lp(a) plasma levels (2). These studies suggest that $\mathrm{Lp}(\mathrm{a})$ may not be effectively catabolized by the LDL receptor under normal conditions. Interestingly, Bottalico et al. (16) have observed that cholesterol loading of macrophages

1. Abbreviations used in this paper: $\mathrm{K} 4$, type 4 kringle repeats; LRP, low density lipoprotein receptor-related protein; MEF, mouse embryonic fibroblasts; PAI-1, plasminogen activator inhibitor-type I; RAP, receptor associated protein; uPA, urokinase-type plasminogen activator. 
leads to an enhancement of $\operatorname{Lp}(\mathrm{a})$ internalization and degradation via induction of a specific receptor that is distinct from the LDL receptor. Thus, it is apparent that in addition to the LDL receptor, another receptor can bind and mediate cellular internalization of $\mathrm{Lp}(\mathrm{a})$.

Several additional members of the LDL receptor family have been identified and may function in $L p(a)$ catabolism. These members include the LDL receptor-related protein (LRP), gp330/megalin, and the VLDL receptor. Evidence has been presented suggesting that one of these receptors, LRP, may bind to a high molecular weight isoform of $\mathrm{Lp}$ (a) (17). Together, members of this family of receptors have important roles in the catabolism of lipoproteins, proteinases, proteinase-inhibitor complexes, and matrix proteins (for review/s, see references 13, and 18-20). Members of this receptor family share structural motifs including cysteine-rich epidermal growth factor-like repeats, cysteine-rich ligand-binding repeats, repeats containing the tetrapeptide sequence tyrosinetryptophan-threonine-aspartic acid, and an asparagine-proline-X-tyrosine sequence within the cytoplasmic tail that is responsible for endocytic signaling in coated pits. All LDL receptor family members bind a $39-\mathrm{kD}$ receptor-associated protein (RAP) that antagonizes ligand binding (21-25), although binding of RAP to the LDL receptor occurs with low affinity. These studies were initiated to investigate the role of the LDL receptor family members in the catabolism of $L p(a)$, and our results indicate that the VLDL receptor binds to $\mathrm{Lp}(\mathrm{a})$ and may play an important role in its catabolism.

\section{Methods}

Proteins. Lp(a) was purified from fresh plasma in the presence of EDTA, and was stored under nitrogen to prevent lipid oxidation as described (26). Unless indicated, Lp(a) from patient 1 was used for all experiments. Phenotyping of $\mathrm{Lp}(\mathrm{a})$ from patient 1 was carried out using the electrophoretic procedure as detailed (27), and two apo(a) phenotypes were identified. $\mathrm{K} 4_{18}$ comprised $\sim 90 \%$, and $\mathrm{K} 4_{27}$, comprised $\sim 10 \%$. Apolipoprotein(a) was purified from $\mathrm{Lp}(\mathrm{a})$ (derived from patient 1 ) by mild reductive cleavage and ultracentrifugation in sucrose as detailed (28). The purified apo(a) demonstrated no contamination of apoB-100 by immunoblot analysis. LDL was purified as described (25). Molecular masses of $1.2 \times 10^{6}, 7.0 \times 10^{5}$, and $5.0 \times$ $10^{5} \mathrm{D}$ were used to calculate the molar concentrations of $\operatorname{Lp}(\mathrm{a}), \mathrm{apo}(\mathrm{a})$, and LDL, respectively, that were isolated from plasma of patient 1. Human VLDL receptor was purified essentially as described (29). Human RAP was expressed in bacteria as a fusion protein with glutathione S-transferase (GST) and purified free of GST as described (21). Human prourokinase (pro-uPA) and two-chain urokinase (uPA) were generously provided by Dr. Jack Henkin (Abbott Laboratories, Abbott Park, IL). Active recombinant plasminogen activator inhibitor type 1 (PAI-1) was purchased from Molecular Innovations (Wayne, MI). UPA was complexed with PAI-1 by mixing at a 1:1 molar ratio in $0.15 \mathrm{M}$ Tris, $0.15 \mathrm{M} \mathrm{NaCl}, \mathrm{pH} 8.0$ at room temperature for $30 \mathrm{~min}$. $\mathrm{Lp}(\mathrm{a})$ and LDL were iodinated by the iodine monochloride method as described (30) with specific activities ranging from 0.4 to $1.0 \mu \mathrm{Ci} / \mu \mathrm{g}$. In the case of $\mathrm{Lp}(\mathrm{a})$, typically $52 \%$ of the label was present in apo(a), and $48 \%$ was present in apoB100.

Cell culture. The LRP-deficient murine cell line, PEA13, and mouse embryonic fibroblasts (MEF) were generously provided by Dr. J. Herz (Dallas, TX), and were grown as described (31). Mouse embryonic F9 teratocarcinoma cells (ATCC CCL 185) were obtained from American Type Culture Collection (Rockville, MD) and were differentiated by treatment with retinoic acid and $\mathrm{Bt}_{2} \mathrm{cAMP}$ as described (32).

Antibodies. Rabbit polyclonal antibodies were prepared against a synthetic peptide corresponding to the human VLDL receptor carboxyl terminus (R2623) as described (24), and the antibody was affinity-purified on peptide-Sepharose as described (33). Rabbit polyclonal antibodies were also prepared against the purified VLDL receptor (R4522), and were purified by chromatography on Protein G-Sepharose, followed by absorption on RAP-Sepharose to remove any RAP-reactive antibodies. Polyclonal antibodies to human LRP (R777) were developed as described (34) and purified by affinity chromatography on LRP-Sepharose followed by chromatography on RAP-Sepharose to remove any anti-RAP reactivity. Antibodies against human RAP (R80) were affinity-purified on RAP-Sepharose as described (34). A rabbit polyclonal antibody against the LDL receptor was provided by J. Herz (Dallas, TX). A monoclonal antibody to uPA was generously provided by Jack Henkin (Abbott Laboratories). Monoclonal antibody 4G3 (35) against apoB100 was provided by Drs. Ross Milne and Yves Marcel (University of Ottawa, Ottawa, Canada). To obtain immunospecific polyclonal antibodies against $\mathrm{Lp}(\mathrm{a})$, rabbits were immunized with purified $\mathrm{Lp}(\mathrm{a})$ from a single donor. The IgG fraction was isolated by chromatography on DEAE cellulose to which cibacron-blue was coupled (36). The isolated antiLp(a) IgG was absorbed repeatedly with immobilized LDL, lys-plasminogen, and fibrinogen until there was no reactivity against these antigens as assessed by immunoblotting. The IgG was then coupled to alkaline phosphatase as described (37). A mouse monoclonal antibody to human $\mathrm{Lp}$ (a) was purchased from Boehringer Mannheim (catalogue no. 1399-314).

Adenovirus-mediated gene transfer. Recombinant replication-deficient adenoviral vectors were prepared as described (38). The recombinant adenoviruses used were as follows: Ad-LacZ (also called Ad.CMVLacZ [38]), an adenovirus containing LacZ cDNA under the human cytomegalovirus enhancer and 3' promoter; Ad-VLDLR (also called Ad.CMVVLDLR [38]), an adenovirus containing the human VLDL receptor under the human cytomegalovirus enhancer and 3'-promoter; and Ad-LDLR (also called Ad.CBhLDLR [38]), an adenovirus containing the human LDLR cDNA under the human cytomegalovirus enhancer with the $\beta$-actin promoter.

PEA13 cells were infected as previously described (29). To assess the effectiveness of the infection with Ad-VLDLR, immunoblotting and RAP ligand blotting of cell extracts were routinely used. To examine infection efficiency of Ad-LacZ, $\beta$-galactosidase expression was evaluated using the chromogenic substrate X-gal as described (39).

Cell internalization and degradation assays. PEA13 cells were infected with Ad-VLDLR and Ad- LacZ in 150-mm dishes. After incubating for $24 \mathrm{~h}$, the cells were transferred to 12-well dishes (Costar Corp., Cambridge MA) at $10^{5}$ cells/well. Cellular internalization and degradation assays were performed $24 \mathrm{~h}$ after replating ( $48 \mathrm{~h}$ after infection). Cells were washed twice with DMEM, and then incubated with DMEM containing $20 \mathrm{mM}$ Hepes, $\mathrm{pH} 7.4,1.5 \%$ BSA, Nutridoma (Boehringer Mannheim Biochemicals, Indianapolis, IN), and $100 \mathrm{U} / \mathrm{ml}$ penicillin $/ 100 \mu \mathrm{g} / \mathrm{ml}$ streptomycin for $1 \mathrm{~h}$ at $37^{\circ} \mathrm{C}$. This media was removed, and then ${ }^{125}$ I-labeled $\mathrm{Lp}$ (a) was added in the same buffer and allowed to incubate with the cells for indicated times. Degradation assays were performed as described (40). All degradation assays included a control in which cells were omitted to measure spontaneous degradation of the ligand. The extent of cell-mediated degradation was determined using chloroquine, an inhibitor of lysosome-mediated degradation, at a final concentration of $0.1 \mathrm{mM}$. Lysosomal degradation accounted for $\sim 70 \%$ of total TCA soluble counts. To measure internalization at the indicated times, cells were washed twice with cold PBS, treated with DMEM containing trypsin $(50 \mu \mathrm{g} /$ $\mathrm{ml})$, proteinase $\mathrm{K}(50 \mu \mathrm{g} / \mathrm{ml}), 100 \mathrm{U} / \mathrm{ml}$ penicillin $/ 100 \mu \mathrm{g} / \mathrm{ml}$ streptomycin, and $0.5 \mathrm{mM}$ EDTA for $15 \mathrm{~min}$ at $4^{\circ} \mathrm{C}$ to remove ligand bound to the cell surface. After centrifugation, the supernatant was removed, and the radioactivity present in the cell pellet was measured. Nonspecific uptake and degradation was measured using a 50-fold molar excess of unlabeled ligands. RAP-blocking experiments were performed using $1 \mu \mathrm{M}$ recombinant RAP. In experiments testing the ability of polyclonal antibodies R777 and R4522 to block degradation 
of $L p(a)$, the heat-inactivated antibodies $(100 \mu \mathrm{g} / \mathrm{ml}$, final concentration) were preincubated with cells for $1 \mathrm{~h}$ before adding ${ }^{125}$ I-labeled ligands. Monoclonal antibody 4G3 was used at a final concentration of $500 \mathrm{nM}$ and added with the ${ }^{125} \mathrm{I}$-labeled ligands. Heparin was used at a final concentration of $100 \mu \mathrm{g} / \mathrm{ml}$.

Preparation of cell extracts. Cell extracts were prepared from cells grown in 100-mm dishes, washed two times briefly in $5 \mathrm{ml}$ of isotonic PBS, and then solubilized in $300 \mu \mathrm{l}$ of $50 \mathrm{mM}$ Hepes, $\mathrm{pH} 7.4,0.5 \mathrm{M}$ $\mathrm{NaCl}, 0.05 \%$ Tween $20,1 \%$ Triton X-100, containing the following proteinase inhibitors: $1 \mathrm{mM}$ phenylmethylsulfonyl fluoride, $25 \mu \mathrm{g} / \mathrm{ml}$ leupeptin, $5 \mu \mathrm{g} / \mathrm{ml}$ D-phenylalanyl-L-proly-L-arginine chloromethyl ketone, and $2 \mu \mathrm{g} / \mathrm{ml}$ pepstatin. The extracts were sheared through a 21-gauge needle, centrifuged at 14,000 rpm for $15 \mathrm{~min}$, and the supernatant was used directly for immunoblotting and RAP ligand-blotting experiments. Protein concentrations were determined by the method of Bradford (41) using BSA as a standard.

Immunoblotting and ligand blotting. Cell extracts were subjected to SDS-PAGE on gradient gels (4-12\% Tris-glycine gels; Novex, San Diego, CA) under nonreducing conditions, and were electrophoretically transferred to nitrocellulose membranes. For experiments examining the different isoforms of $\mathrm{Lp}(\mathrm{a})$ by SDS-PAGE, $4 \%$ gels were used (Novex, San Diego, CA). Immunoblotting and ligand-blotting experiments were performed as described (29), using antibody concentrations of $1 \mu \mathrm{g} / \mathrm{ml}$. RAP ligand-blotting experiments were performed as described (24) using $25 \mathrm{nM}$ RAP, and the RAP was detected using R80 IgG $(1 \mu \mathrm{g} / \mathrm{ml})$. As a control, RAP was omitted from the protocol. In ligand-blotting experiments using $\mathrm{Lp}(\mathrm{a})$, the membranes were incubated with $50 \mathrm{nM} \mathrm{Lp}(\mathrm{a})$ in the absence or presence of $1 \mu \mathrm{M}$ RAP in $50 \mathrm{mM}$ Tris $\mathrm{pH} 7.4,150 \mathrm{mM} \mathrm{NaCl}, 5 \mathrm{mM} \mathrm{CaCl}_{2}, 3 \%$ nonfat dry milk, and $0.05 \%$ Tween 20 overnight at $4^{\circ} \mathrm{C}$. After washing, the bound $\mathrm{Lp}(\mathrm{a})$ was detected with a rabbit anti-Lp(a)-alkaline phosphatase conjugate. Antibody binding to $\mathrm{Lp}(\mathrm{a})$ was visualized by adding $25 \mathrm{~mL}$ of Nitro Blue Tetrazolium $(0.33 \mathrm{mg} / \mathrm{ml}, \mathrm{N}-6876)$ and 5-Bromo-4-chloro-3-Indoyl phosphate $(0.165 \mathrm{mg} / \mathrm{ml}$, B-8503; Sigma Chemical Co., St. Louis, MO) dissolved in $100 \mathrm{mM}$ Tris, $\mathrm{pH}$ 9.5, containing $100 \mathrm{mM} \mathrm{NaCl}, 5 \mathrm{mM} \mathrm{MgCl}, 0.02 \%$ sodium azide.

Clearance of $L p(a)$ from mice. For clearance experiments, mice that were homozygous for a disruption in the VLDL receptor gene (VLDLR -/-) created by homologous recombination (42) were obtained from Jackson Laboratories (Strain B6,129-Vldlr $\stackrel{\text { tmlHer }}{\text {; Bar }}$ Harbor, ME). Wild-type mice (of the same parental strain as VLDLR-deficient mice, B6,129), were obtained from Jackson Laboratories and were used as controls for these experiments. $100 \mu \mathrm{g}$ of $\mathrm{Lp}(\mathrm{a})$ in a total volume of $100 \mu \mathrm{l}$ buffer (0.05 M Tris, $\mathrm{pH}$ 8.0, $1 \mathrm{mM} \mathrm{M}$ EDTA, $0.15 \mathrm{M} \mathrm{NaCl}$ ) was injected into the tail vein of each of four VLDLR - / - and five wild-type adult female mice, without anesthesia. Blood was drawn by retroorbital puncture $2 \mathrm{~min}$, and 2.5, 5, 10, and $22 \mathrm{~h}$ after injection using a local anesthetic of tetracaine hydrochloride $0.5 \%$ (Bausch and Lomb Pharmaceutical Division, Tampa, FL) and heparinized hematocrit capillary tubes (catalogue no. 260950; Curin Matheson Scientific, Inc., Houston, TX). The blood was adjusted to $20 \mathrm{mM}$ EDTA and kept on ice until centrifuged at $1200 \mathrm{~g}$ for $5 \mathrm{~min}$. The plasma was then stored at $-70^{\circ} \mathrm{C}$. Within $1 \mathrm{wk}, 0.1 \mu \mathrm{l}$ of plasma from each time point was subjected to SDS-PAGE under reducing conditions on $4 \%$ Tris-glycine gels (Novex, San Diego, CA). The gels were transferred electrophoretically to nitrocellulose, and immunoblotting was performed as described (29) using a monoclonal antibody to human $\mathrm{Lp}(\mathrm{a})$ at $1 \mu \mathrm{g} / \mathrm{ml}$. To quantify the amount of $\mathrm{Lp}(\mathrm{a})$ antigen present in the samples, each gel contained standards that were prepared by diluting known amounts of purified $\mathrm{Lp}(\mathrm{a})$ from patient 1 (0.12-9.3 ng final amounts on gel) into mouse plasma. The bands were quantified after scanning using Bio Image Visage 4.6P Software (Millipore Corp., Bedford, MA), and a standard curve was constructed for each gel. A plot of the intensity (absorbance X area of band) versus concentration for the standards generated a linear response, and the best-fit line was determined by linear regression analysis. The concentration of the unknowns were determined from the best-fit parameters of the standard curve.
Immunohistochemical localization of VLDL receptor. Immunohistochemical staining was performed on 90 formalin-fixed, paraffinembedded human tissues including 90 coronary atherectomy and endarterectomy specimens using the affinity-purified anti-VLDL receptor IgG (R2623) at a concentration of $1.7 \mu \mathrm{g} / \mathrm{ml}$. The specificity of the antibody was confirmed by blocking immunoreactivity with a 10fold molar excess peptide that was used to immunize the rabbit. To identify macrophages, smooth muscle cells, and endothelial cells, staining was also performed using $7.0 \mu \mathrm{g} / \mathrm{ml}$ anti-CD68 (monoclonal antibody KP-1, catalogue no. M814; Dako Corp., Carpinteria, CA), $0.1 \mu \mathrm{g} / \mathrm{ml}$ anti smooth muscle actin (monoclonal antibody 1A4, catalogue no. M851; Dako) and $0.03 \mu \mathrm{g} / \mathrm{ml}$ anti-von Willebrand Factor (monoclonal antibody F8/86, catalogue no. M616; Dako). Deparaffinized and rehydrated 5- $\mu \mathrm{m}$ tissue sections were blocked with normal goat serum and $3 \% \mathrm{H}_{2} \mathrm{O}_{2}$ in water, washed in PBS, and incubated with the appropriate primary antibody for $0.5-2 \mathrm{~h}$ at $37^{\circ} \mathrm{C}$. Specimens were washed in PBS, and primary antibodies were detected using biotin-labeled secondary antibodies (BioGenex Labs, San Ramon, CA) for $20 \mathrm{~min}$ at room temperature. Slides were again washed in PBS and reacted with peroxidase-conjugated streptavidin with an incubation time of $20 \mathrm{~min}$ at room temperature, and were developed with 3,3'diaminobenzidine (DAB). Slides were then washed in distilled water, counterstained with hematoxylin, dehydrated, mounted with Permount (Fisher Scientific Co., Fairlawn, NJ) and observed on a microscope (Carl Zeiss, Inc., Thornwood, NY). For the double-staining experiments, antibodies were sequentially detected using peroxidase-DAB (for VLDL receptor antigen) and alkaline phosphatase-fast red (for CD68 antigen or for $\alpha$-actin antigen) using the same procedure as above. Positive control slides, nonimmune negative controls, and processing controls were performed for each antigen stained.

\section{Results}

The VLDL receptor mediates cellular internalization and degradation of ${ }^{125}$ I-labeled $\operatorname{Lp}(a)$. Initial experiments focused on the capacity of LDL receptor family members to mediate the cellular uptake and degradation of ${ }^{125} \mathrm{I}$-labeled Lp(a). For these experiments, mouse embryonic fibroblasts (MEF) that express LRP, and mouse embryonic fibroblasts genetically deficient in LRP (PEA13 fibroblasts) (31) were used. Neither of these cell lines express detectable levels of gp330 or the VLDL receptor (29). They do, however, express the LDL receptor. To study the role of the VLDL receptor in the catabolism of $\mathrm{Lp}(\mathrm{a})$, our strategy involved introducing the human VLDL receptor cDNA into PEA13 fibroblasts, and determining if an enhanced uptake of ${ }^{125}$ I-labeled $\mathrm{Lp}(\mathrm{a})$ occurred in these cells. An adenoviral vector (Ad-VLDLR) was chosen to introduce the human VLDL receptor cDNA into PEA13 fibroblasts since adenovirus-mediated gene transfer to mammalian cells in culture has proven to be a highly effective means for introducing genes into a variety of cell lines (43). As a control, PEA13 fibroblasts were also infected with an adenovirus vector, Ad-LacZ, containing the LacZ cDNA instead of the VLDL receptor cDNA.

The expression of the VLDL receptor, LDL receptor, and LRP in these cell lines was examined by immunoblot analysis. Fig. 1 shows an immunoblot of cell extracts from PEA-13 cells infected with Ad-VLDLR (left lanes), PEA-13 cells infected with Ad-LacZ (middle lanes), and wild-type MEF (right lanes). Immunoblotting with an anti-VLDL receptor IgG (Fig. 1, A) confirmed that PEA13 fibroblasts infected with Ad-VLDLR express the VLDL receptor, while those infected with AdLacZ and MEF do not express detectable levels of the VLDL receptor. Immunoblotting with an anti-LDL receptor IgG re- 
A

B

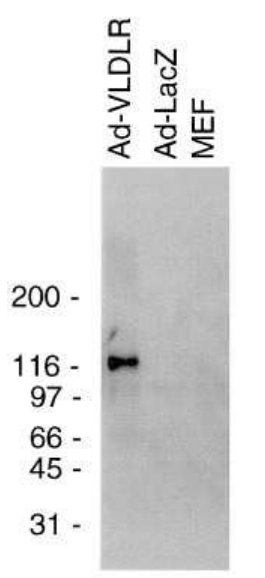

Anti-VLDLR

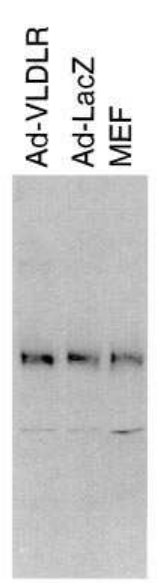

Anti-LDLR
C

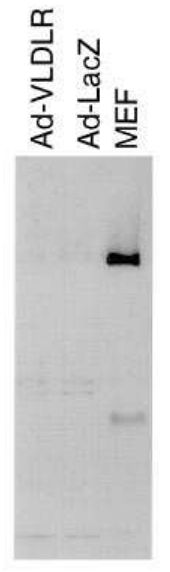

Anti-LRP
D

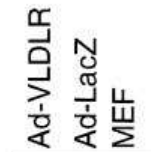

RAP ligand

Blot

Figure 1. Immunoblot analysis $(A-C)$ and RAP ligand blot analysis (D) of cell extracts from murine fibroblasts. Cell extracts prepared from PEA13 fibroblasts infected with Ad-VLDLR (left lanes),

Ad-LacZ (middle lanes), or from MEF (right lanes) were subjected to SDS-PAGE on $4-12 \%$ gradient gels under nonreducing conditions, transferred to nitrocellulose, and incubated overnight at $4^{\circ} \mathrm{C}$ with $(A)$ anti-VLDL receptor IgG $(1 \mu \mathrm{g} / \mathrm{ml}),(B)$ anti-LDL receptor IgG $(1$ $\mu \mathrm{g} / \mathrm{ml}),(C)$ anti-LRP IgG $(1 \mu \mathrm{g} / \mathrm{ml})$, and $(D) 25 \mathrm{nM}$ RAP. The RAP ligand blot $D$ was washed and incubated for $1 \mathrm{~h}$ with anti-RAP IgG (1 $\mu \mathrm{g} / \mathrm{ml})$. All blots were washed and incubated with goat anti-rabbit IgG-horseradish peroxidase conjugate. The antigen-antibody complexes were visualized by use of the Renaissance chemiluminescence kit. $20 \mu \mathrm{g}$ of total protein were applied to each lane.

vealed that all cell lines express comparable levels of the LDL receptor (Fig. $1 \mathrm{~B}$ ). As expected, the PEA-13 fibroblasts infected with Ad-VLDLR or Ad-LacZ do not express any LRP, while MEF express LRP (Fig. $1 C$ ). The integrity of the expressed VLDL receptor was examined by RAP ligand-blotting experiments on cell extracts (Fig. $1 D$ ). These experiments confirm that the VLDL receptor expressed in PEA13 fibroblasts after infection with Ad-VLDLR is able to bind RAP. RAP also detects LRP present in MEF, but as previously reported (24) does not detect the LDL receptor by this technique.

Cellular uptake experiments were conducted using all three cell lines. For these uptake experiments, ${ }^{125}$ I-labeled $\mathrm{Lp}(\mathrm{a})$ was incubated with the cells for varying times at $37^{\circ} \mathrm{C}$. At the indicated time, the medium was removed and the amount of ${ }^{125}$ I-labeled Lp(a) that had been degraded to acidsoluble material was measured. The cells were washed and treated with proteinases to release surface-bound radioligand. Radioactivity that resisted proteinase release was considered to be intracellular. ${ }^{125}$ I-labeled $\mathrm{Lp}$ (a) was internalized by cells expressing the VLDL receptor (Fig. $2 A$ ) and reached a steady-state intracellular level with time. Once internalized, the ${ }^{125}$ I-labeled Lp(a) was degraded, as measured by the appearance of acid-soluble material secreted into the medium (Fig. $2 \mathrm{~B}$ ). Both the internalization and degradation of ${ }^{125} \mathrm{I}-$ labeled Lp(a) were diminished when RAP, a molecule known to inhibit ligand binding to the VLDL receptor $(24,44)$, was included during the incubation. These results indicate that

cells expressing the VLDL receptor are capable of mediating the cellular uptake and degradation of $\mathrm{Lp}(\mathrm{a})$. In contrast to the VLDL receptor-expressing cells, cells deficient in this receptor (PEA-13 fibroblasts infected with Ad-LacZ, Fig. 2, $C$ and $D$ ) and MEF cells, which express LRP (Fig. 2, $E$ and $F$ ), were unable to internalize or degrade significant amounts of ${ }^{125} \mathrm{I}$ labeled Lp(a). Furthermore, since all of these cells express the LDL receptor, and since they are identical in their ability to internalize and degrade $\operatorname{LDL}(31,45)$, the results also suggest that the LDL receptor is not very effective in binding and mediating the cellular uptake of $\mathrm{Lp}(\mathrm{a})$ in culture conditions where this receptor is downregulated. We did notice a twofold increase in the amount of ${ }^{125} \mathrm{I}-\mathrm{Lp}$ (a) internalized and degraded by PEA-13 fibroblasts cultured under conditions where the LDL receptor is upregulated (i.e., by culturing cells with lovastatin in lipoprotein-deficient serum), confirming studies (14) showing that the LDL receptor can mediate the catabolism of $\operatorname{Lp}(\mathrm{a})$.
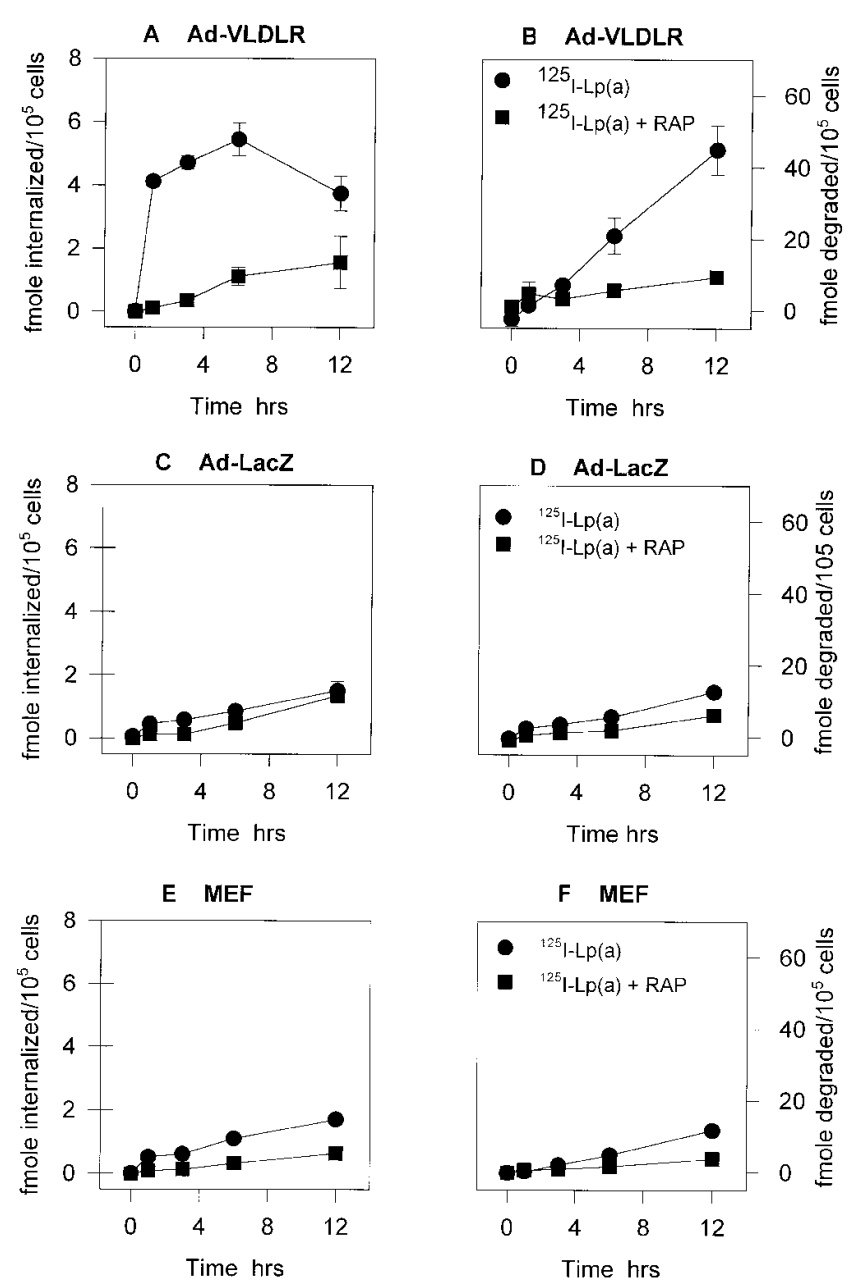

Figure 2. Cells expressing the human VLDL receptor internalize and degrade ${ }^{125}$ I-labeled Lp(a). PEA13 fibroblasts infected with Ad-VLDLR ( $A$ and $B$ ), PEA13 fibroblasts infected with Ad-LacZ $(C$ and $D)$, or MEF ( $E$ and $F)$ were plated into wells $\left(10^{5}\right.$ cells/well), and $10 \mathrm{nM}^{125}$ I-labeled $\mathrm{Lp}(\mathrm{a})$ was added to each well. At indicated times, the extent of internalization $(A, C$, and $E)$ and degradation $(B$, $D$, and $F$ ) were measured. In control experiments, $1 \mu \mathrm{M}$ RAP was included along with $10 \mathrm{nM}^{125}$ I-labeled Lp(a) during the incubation.

Each data point represents the average of duplicate determinations. 
A

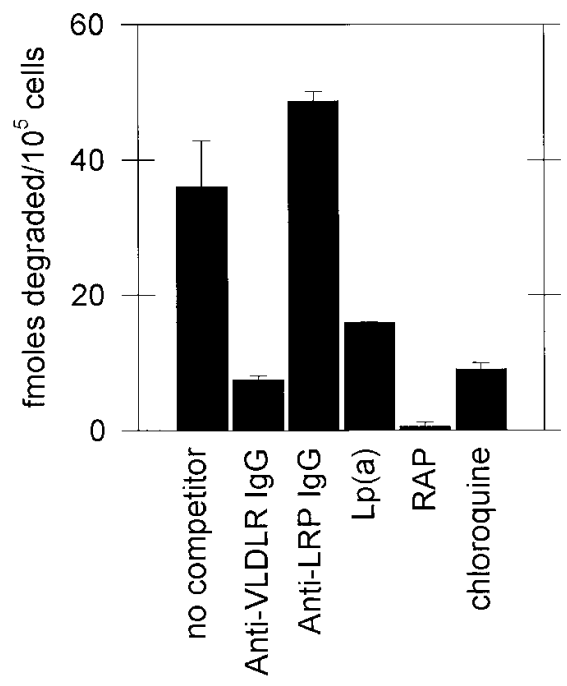

B

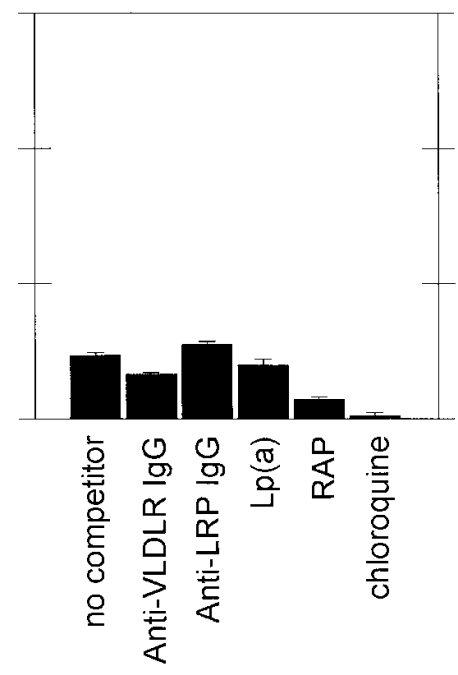

C

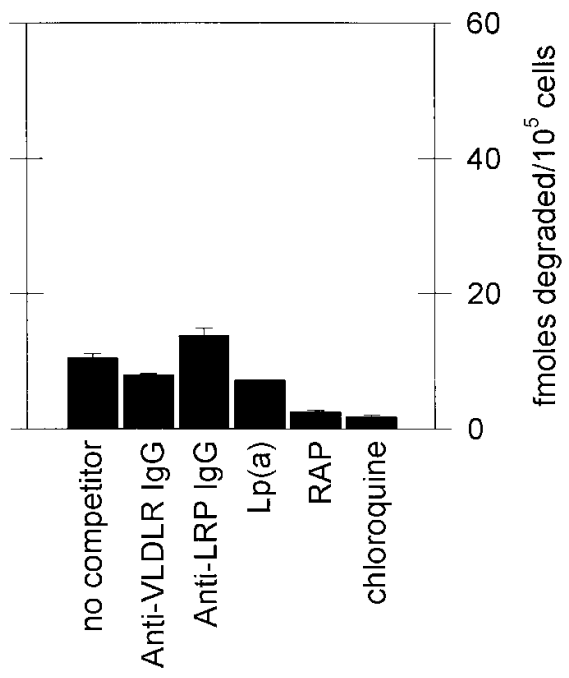

Figure 3. VLDL receptor antibodies inhibit degradation of ${ }^{125}$ I-labeled Lp(a) by murine fibroblasts expressing the human VLDL receptor. PEA13 fibroblasts infected with Ad-VLDLR $(A)$, PEA13 fibroblasts infected with Ad-LacZ $(B)$, or MEF $(C)$ were plated into wells $\left(10^{5}\right.$ cells/ well) and incubated with $10 \mathrm{nM}{ }^{125} \mathrm{I}$-labeled $\mathrm{Lp}(\mathrm{a})$ for $12 \mathrm{~h}$ at $37^{\circ} \mathrm{C}$. After incubation, the amount of ${ }^{125}$ I-labeled Lp(a) degraded in the absence or presence of competitors was measured. Competitors include the following: anti-VLDL receptor IgG $(100 \mu \mathrm{g} / \mathrm{ml})$, anti-LRP IgG (100 $\mu \mathrm{g} / \mathrm{ml}), \mathrm{un}-$ labeled $\mathrm{Lp}(\mathrm{a})(500 \mathrm{nM})$, RAP $(1 \mu \mathrm{M})$, and chloroquine $(0.1 \mathrm{mM})$. The data shown are the average of duplicate determinations.

Previous studies (32) demonstrated that gp330 can bind and mediate the catabolism of LDL, and thus it was of interest to determine if $\mathrm{Lp}(\mathrm{a})$ is a ligand for gp330. To investigate this question, cultured mouse F9 tetratocarcinoma cells were treated with retinoic acid and dibutyryl cyclic AMP. This treatment increases expression of gp330 50-fold while reducing levels of the LDL receptor (32). When incubated with $10 \mathrm{nM}^{125} \mathrm{I}-$ labeled Lp(a), neither the control cells or the treated cells were able to internalize or degrade ${ }^{125}$ I-labeled Lp(a). Immunoblotting experiments confirmed that gp330 expression was increased in the F9 cells upon treatment. Control experiments confirmed that gp330 was functional; the increased expression of gp330 in the treated cells resulted in a 25 -fold increase in the amount of ${ }^{125} \mathrm{I}$-labeled pro-uPA degraded ( 57 fmoles ${ }^{125} \mathrm{I}$ labeled pro-uPA degraded $/ 10^{5}$ cells per $6 \mathrm{~h}$ in treated cells vs. 2.3 fmoles ${ }^{125}$ I-labeled pro-uPA degraded $/ 10^{5}$ cells per $6 \mathrm{~h}$ in control cells). Thus, gp330 does not appear capable of mediating the cellular catabolism of this isoform of $\mathrm{Lp}(\mathrm{a})$.

The cellular uptake of $L p(a)$ is blocked by anti-VLDL receptor IgG. To confirm further that the VLDL receptor is responsible for mediating the uptake of ${ }^{125}$ I-labeled $\mathrm{Lp}(\mathrm{a})$, polyclonal antibodies against the VLDL receptor were used to determine if they could block the cellular uptake of this ligand. The results (Fig. $3 A$ ) demonstrate that a rabbit polyclonal IgG against the VLDL receptor greatly diminished the amount of ${ }^{125}$ I-labeled $\mathrm{Lp}(\mathrm{a})$ that was degraded in cells expressing the VLDL receptor. A control $\mathrm{IgG}$, prepared against the $515-\mathrm{kD}$ subunit of LRP, was unable to prevent degradation of this ligand. These results confirm that the VLDL receptor is responsible for cellular uptake of ${ }^{125}$ I-labeled Lp(a) in these cells. Fig. $3 A$ also shows the effect of other molecules on the degradation of ${ }^{125}$ I-labeled $\mathrm{Lp}(\mathrm{a})$ in the three cell lines. A 50 -fold molar excess of unlabeled $\mathrm{Lp}(\mathrm{a})$ reduced the extent of degradation. The degradation was also blocked by RAP and chloro- quine, an inhibitor of lysosomal-mediated degradation. As in previous experiments, the degradation of ${ }^{125} \mathrm{I}$-labeled $\mathrm{Lp}(\mathrm{a})$ is not efficient in cells lacking the VLDL receptor (compare data of $A$ with data of $B$ and $C$; Fig. 3).

The VLDL receptor binds $L p(a)$ in vitro. To measure directly an interaction between $\mathrm{Lp}(\mathrm{a})$ and the VLDL receptor, ligand blotting experiments were performed. In these experiments, purified VLDL receptor and LRP were subjected to SDS-PAGE, transferred to nitrocellulose, and then incubated with $\mathrm{Lp}(\mathrm{a})$ or with uPA:PAI-1 complexes, a ligand for both the VLDL receptor and LRP. Ligand binding to immobilized receptors was detected with specific antibodies. The results of this experiment (Fig. 4) demonstrate that $\mathrm{Lp}$ (a) binds to the VLDL receptor, but not to LRP, when the receptors are immobilized on nitrocellulose (Fig. 4 A, left panel). The binding of $\mathrm{Lp}$ (a) to the VLDL receptor was prevented when RAP was included during the incubation (Fig. $4 \mathrm{~A}$, right panel). These experiments confirm that $\mathrm{Lp}(\mathrm{a})$ interacts with the VLDL receptor in vitro in a RAP-sensitive manner, which is a characteristic feature of the interaction of other ligands with this receptor (24). As a control, blots were also probed with uPA: PAI-1, which is known to bind to both of these receptors (29, 46). The results, shown in Fig. $4 B$, indicate that the purified LRP used in these experiments is capable of binding ligands. Together, these studies confirm that this isoform of $\mathrm{Lp}(\mathrm{a})$ binds to the VLDL receptor in vitro, but not to LRP. Due to the similarities in structure of apo(a) and plasminogen, we tested the ability of plasminogen to bind to the VLDL receptor by ligand-blotting analysis. It is interesting to note that plasminogen did not bind to the VLDL receptor (data not shown), suggesing that the VLDL receptor does not appear capable of binding all kringle-containing proteins.

Concentration dependence of $L p(a)$ degradation by cells expressing the human VLDL receptor and human LDL recep- 

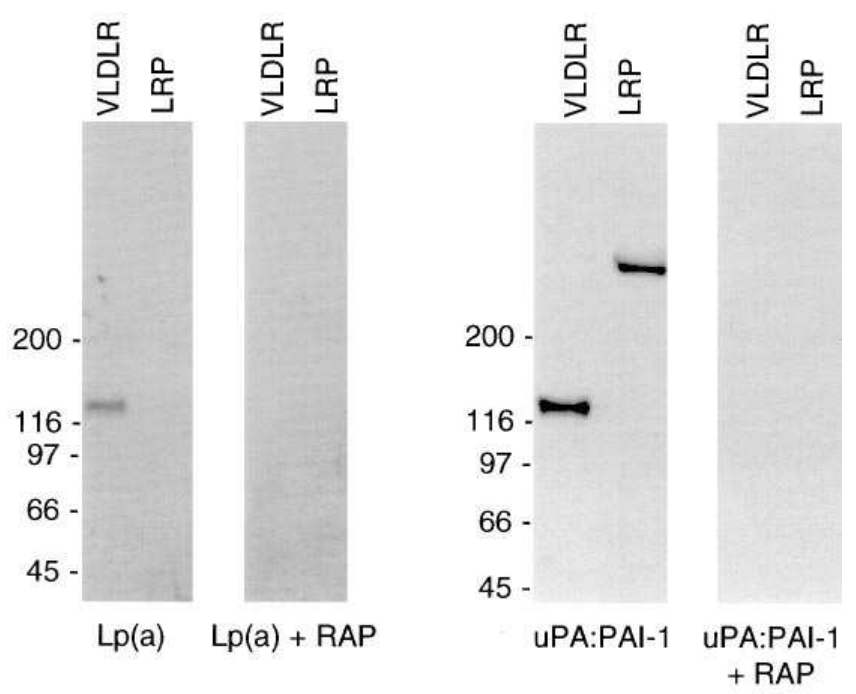

Figure 4. Lp(a) binds the VLDL receptor by ligand blot analysis. (A) Purified VLDL receptor and LRP $(0.1 \mu \mathrm{g} / \mathrm{lane})$ were subjected to SDS-PAGE on $4-12 \%$ gradient gels under nonreducing conditions, transferred to nitrocellulose and incubated overnight at $4^{\circ} \mathrm{C}$ with 50 $\mathrm{nM} \mathrm{Lp}(\mathrm{a})$, either in the absence (left panels) or presence (right panels) of $1 \mu$ M RAP. The bound Lp(a) was detected by incubation with alkaline phosphatase-conjugated anti-Lp(a) IgG. (B) Purified VLDL receptor and LRP $(0.1 \mu \mathrm{g} / \mathrm{lane})$ were subjected to SDS-PAGE on $4-12 \%$ gradient gels under nonreducing conditions, transferred to nitrocellulose, and incubated overnight at $4^{\circ} \mathrm{C}$ with $50 \mathrm{nM}$ uPA:PAI-1, either in the absence or presence of $1 \mu \mathrm{M}$ RAP. The blots were washed and incubated for $1 \mathrm{~h}$ with an anti-uPA IgG $(1 \mu \mathrm{g} / \mathrm{ml})$. After washing, the blots were incubated with a goat anti-mouse IgG-horseradish peroxidase conjugate, and the antigen-antibody complexes were visualized by use of the Renaissance chemiluminescence kit.

tor. Overexpression of the LDL receptor results in a more rapid clearance of $\mathrm{Lp}(\mathrm{a})$ after injection into mouse plasma (14). While the mouse fibroblasts used in this study do express the LDL receptor, these cell lines are ineffective in cataboliz- ing ${ }^{125} \mathrm{I}-\mathrm{Lp}(\mathrm{a})$. This result could be due to low levels of LDL receptor present in these cells, or to species differences. To confirm that the LDL receptor is able to catabolize the $L p(a)$ used in these experiments, and to compare the extent of degradation of ${ }^{125}$ I-labeled Lp(a) mediated by the VLDL receptor with that mediated by the LDL receptor, PEA-13 fibroblasts were infected with Ad-VLDLR, Ad-LDLR, an adenovirus containing the human LDL receptor cDNA, or Ad-LacZ as a control. After infection, the cells were incubated with increasing concentrations of ${ }^{125} \mathrm{I}$-labeled $\mathrm{Lp}(\mathrm{a})$, and the extent of degradation after a 13-h incubation was measured. The results of this experiment are shown in Fig. 5, and indicate that cells overexpressing either the VLDL receptor or LDL receptor are both effective in mediating the degradation of ${ }^{125} \mathrm{I}$-labeled $\mathrm{Lp}(\mathrm{a})$. Lp(a) degradation mediated by cells expressing the VLDL receptor was completely inhibited by RAP, while Lp(a) degradation mediated by cells expressing the LDL receptor was only partially inhibited by RAP, most likely due to the low affinity of RAP for the LDL receptor (25). The extent of degradation mediated by the VLDL receptor is significant when compared to that mediated by the LDL receptor, and the dose response curve indicates that substantial uptake and degradation of Lp(a) by cells expressing either receptor occurs at levels of $\mathrm{Lp}(\mathrm{a})$ that are considered to constitute a risk factor for cardiovascular disease (above $30 \mathrm{mg} / \mathrm{dL}$ or $83 \mathrm{nM}$ ).

LDL effectively inhibits catabolism of $L p(a)$ mediated by the LDL receptor, but not that mediated by the VLDL receptor. Since LDL is not a ligand for the VLDL receptor, experiments were conducted to examine the effect of LDL on the catabolism of $\mathrm{Lp}(\mathrm{a})$. In these experiments, PEA-13 fibroblasts infected with either Ad-VLDLR or Ad-LDLR were incubated with ${ }^{125}$ I-labeled Lp(a) $(70 \mathrm{nM})$ in the presence of increasing concentrations of LDL. The results (Fig. 6) indicate that catabolism of $\mathrm{Lp}(\mathrm{a})$ mediated by the LDL receptor is inhibited by LDL, whereas catabolism of Lp(a) mediated by the VLDL receptor is not as sensitive to increasing concentrations of LDL.

Monoclonal antibodies to apolipoprotein B100 do not block uptake of $L p(a)$ by the VLDL receptor. To identify the por-
A

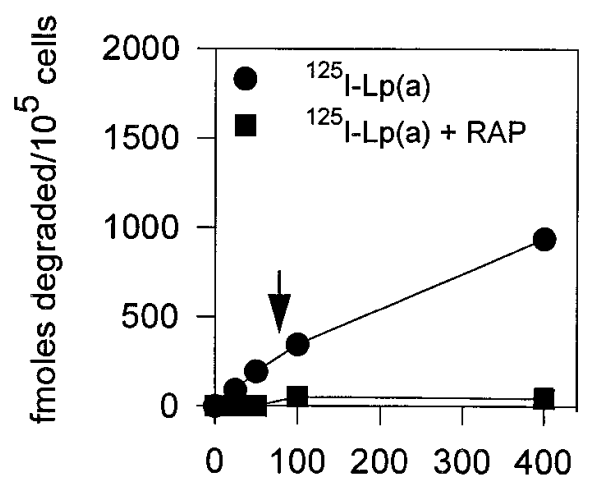

B

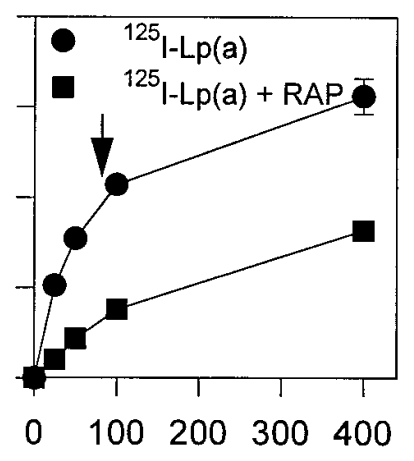

C

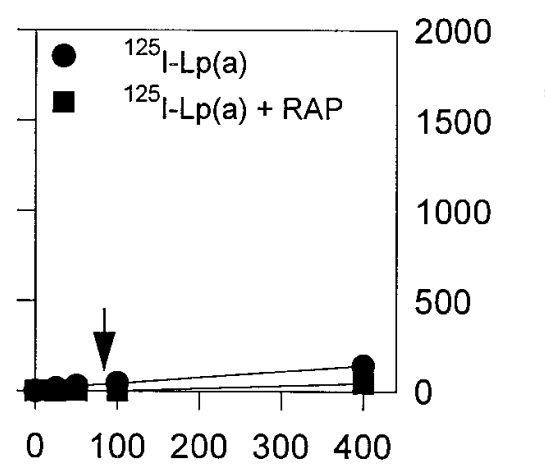

\section{Lp(a) concentration, nM}

Figure 5. Dose-dependent degradation of ${ }^{125}$ I-labeled Lp(a) by cells expressing the human VLDL receptor or human LDL receptor. PEA-13 fibroblasts infected with Ad-VLDLR $(A)$, with Ad-LDLR $(B)$, or with Ad-LacZ $(C)$ were plated into wells $\left(10^{5}\right.$ cells per well), and increasing amounts of ${ }^{125} \mathrm{I}$-labeled $\mathrm{Lp}(\mathrm{a})$ in the absence or presence of $1 \mu \mathrm{M}$ RAP were added to each well. After $13 \mathrm{~h}$, the extent of degradation was measured. Each point represents the average of duplicate determinations. The arrow indicates the concentration of $\mathrm{Lp}(\mathrm{a})$ above which is considered a risk factor for cardiovascular disease. 


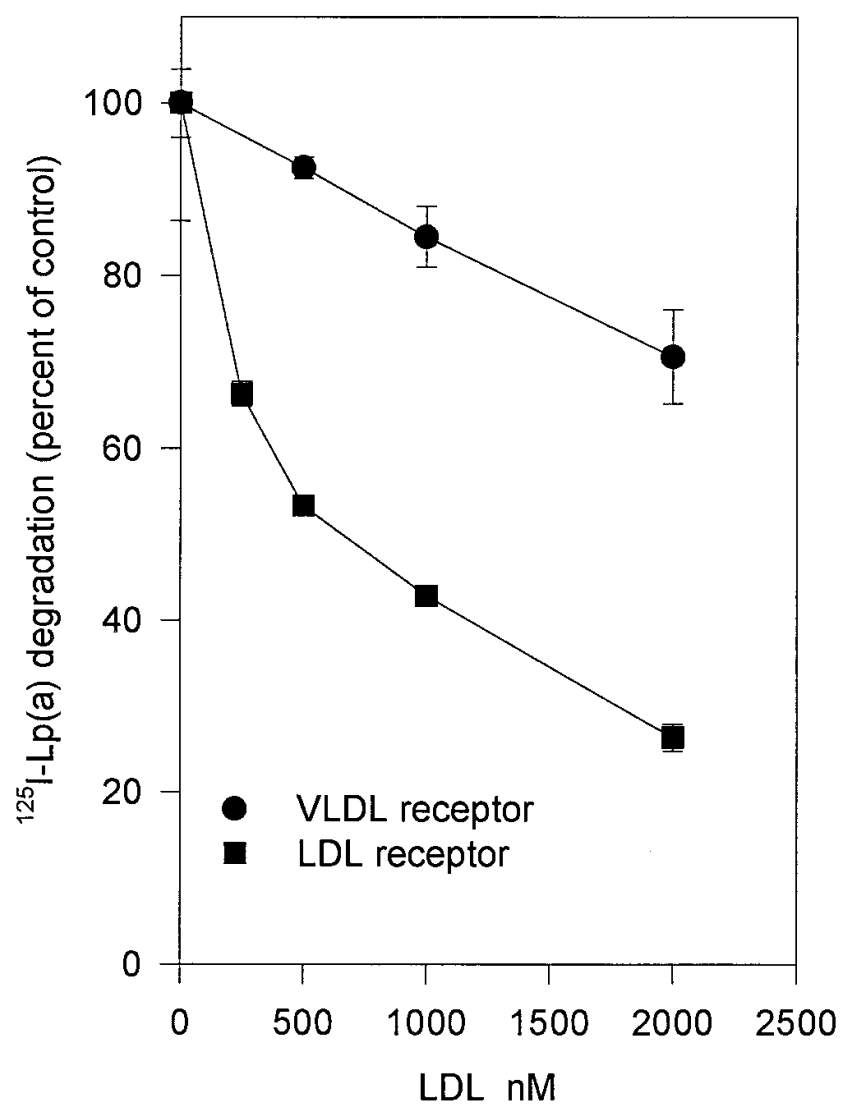

Figure 6. LDL does not effectively compete for catabolism of ${ }^{125} \mathrm{I}-$ labeled Lp(a) mediated by the VLDL receptor. PEA13 fibroblasts infected with Ad-VLDLR, or PEA13 fibroblasts infected with Ad-LDLR were incubated with $70 \mathrm{nM}^{125}$ I-labeled Lp(a) in the presence of the indicated concentration of LDL. After $12 \mathrm{~h}$, the extent of degradation was determined. Each data point represents the average of duplicate determinations.

tion of $\mathrm{Lp}(\mathrm{a})$ responsible for binding to the VLDL receptor, initial experiments used an anti-apolipoprotein B100 (apoB100) monoclonal antibody, 4G3, which is known to block catabolism of LDL (35). The effect of $4 \mathrm{G} 3$ on the catabolism of
${ }^{125}$ I-labeled Lp(a) and ${ }^{125}$ I-labeled LDL in PEA-13 fibroblasts infected with Ad-VLDLR was measured. Monoclonal antibody 4G3 had little effect on cellular degradation of ${ }^{125}$ I-labeled $\mathrm{Lp}$ (a) (reducing the amount degraded by $14 \%$ ) by PEA-13 cells expressing the VLDL receptor (data not shown). In contrast, monoclonal antibody $4 \mathrm{G} 3$ was effective in preventing degradation of ${ }^{125}$ I-LDL by these cells, reducing the amount degraded by $88 \%$. Together, these results suggest that the LDL receptor-binding domain of apoB100 is not the determinant on $\mathrm{Lp}(\mathrm{a})$ that is recognized by the VLDL receptor. This possibility is consistent with the fact that the VLDL receptor is ineffective in binding and internalizing $\operatorname{LDL}(47,48)$.

Apo (a) inhibits the uptake of $L p(a)$ by the VLDL receptor. Since monoclonal antibodies to apoB100 were unable to prevent catabolism of $\operatorname{Lp}(\mathrm{a})$, it was of interest to determine if apo(a) was able to block catabolism of ${ }^{125} \mathrm{I}$-labeled Lp(a). Fig. 7 demonstrates that a 50-fold molar excess of apo(a) was effective in blocking both the internalization (Fig. $7 \mathrm{~A}$ ) and degradation (Fig. $7 B$ ) of ${ }^{125} \mathrm{I}$-labeled $\mathrm{Lp}(\mathrm{a})$. These results suggest that apo(a) is responsible for mediating the interaction of $\mathrm{Lp}(\mathrm{a})$ with the VLDL receptor. Interestingly, another ligand for the VLDL receptor, UPA:PAI-1 complexes $(29,46)$, was also able to compete for the catabolism of Lp(a) (Fig. 7).

$L p(a)$ isoforms are differentially recognized by the VLDL receptor. Apo(a) is known to demonstrate considerable size polymorphism (49) due to multiple tandem repeats of the K4 type 2 encoding sequence (50). Given the known heterogeneity of $\mathrm{Lp}(\mathrm{a})$ it was of interest to determine if different isoforms of $\operatorname{Lp}(\mathrm{a})$ are recognized by the VLDL receptor. Consequently, $\mathrm{Lp}$ (a) from several subjects was purified. The apo(a) from each subject was analyzed by SDS-PAGE, transferred to nitrocellulose, and subjected to immunoblot analysis (Fig. 8). To compare the catabolism of these isoforms, $70 \mathrm{nM}$ of ${ }^{125} \mathrm{I}$-labeled $\mathrm{Lp}(\mathrm{a})$ of each isoform (with the exception of subject 4 where $29 \mathrm{nM}$ was used) was incubated with cells infected with AdVLDLR, Ad-LDLR, or Ad-LacZ, and the extent of degradation was measured. The results (Table I) demonstrate that four of the five $\mathrm{Lp}(\mathrm{a})$ isoforms tested were internalized and degraded by cells expressing the VLDL receptor, although the extent of degradation was dependent on the $\mathrm{Lp}(\mathrm{a})$ isoform. Cells expressing the VLDL receptor did not internalize or de-
A

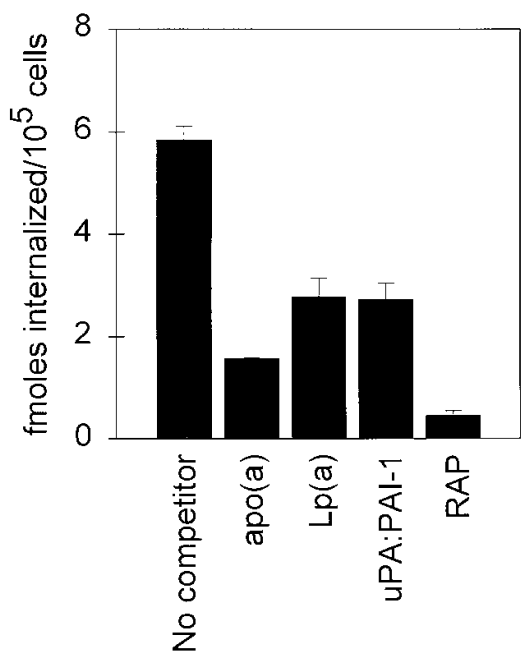

B

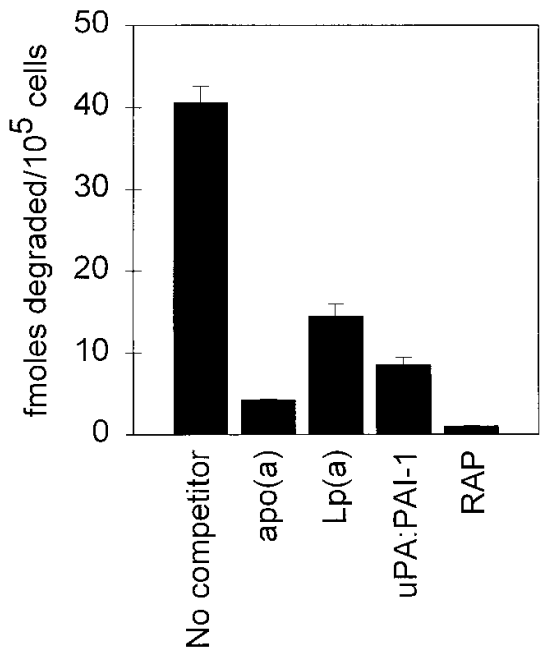

Figure 7. Apo(a) inhibits the uptake and degradation of $L p(a)$ by cells expressing the VLDL receptor. PEA13 fibroblasts infected with Ad-VLDLR were plated into wells $\left(10^{5}\right.$ cells/well $)$ and incubated with $10 \mathrm{nM}$ ${ }^{125} \mathrm{I}$-labeled $\mathrm{Lp}(\mathrm{a})$ for $12 \mathrm{~h}$ at $37^{\circ} \mathrm{C}$. Shown are the amount of ${ }^{125}$ I-labeled $\mathrm{Lp}(\mathrm{a})$ internalized $(A)$ or degraded $(B)$ in the absence of competitor, or in the presence of either apo(a) (500 nM), unlabeled Lp(a) (500 nM), uPA: PAI-1 $(500 \mathrm{nM})$, or RAP $(1 \mu \mathrm{M})$. The data shown are the average of duplicate determinations. 


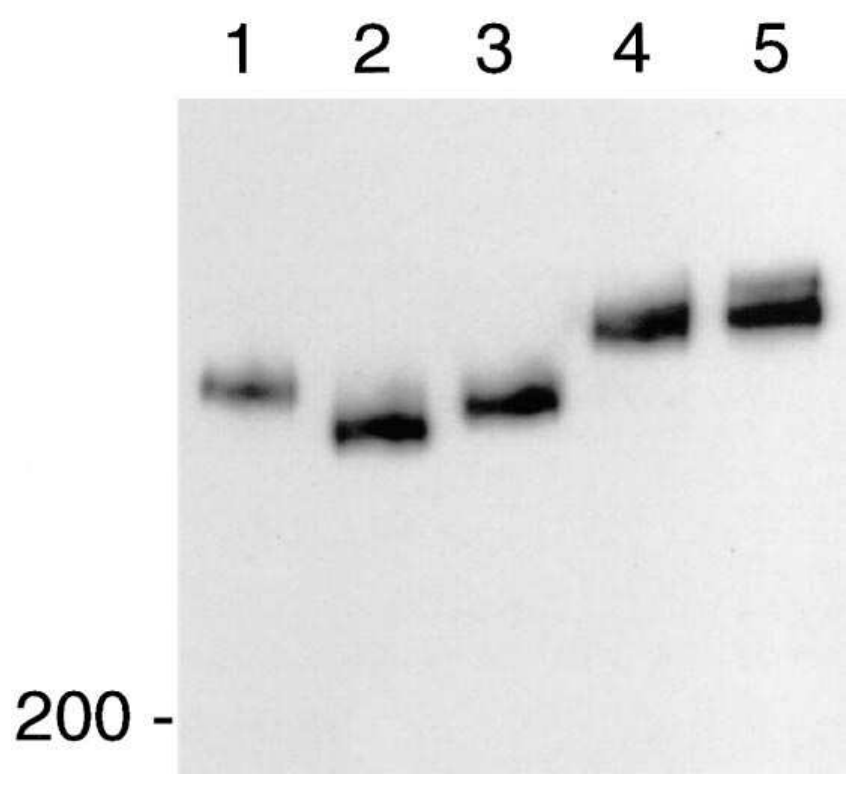

Figure 8. Analysis of apo(a) from $\mathrm{Lp}(\mathrm{a})$ isoforms isolated from subjects by immunoblot analysis after SDS-PAGE. $3.2 \mathrm{ng}$ of $\mathrm{Lp}(\mathrm{a})$ from each subject was analyzed by SDS-PAGE on $4 \%$ polyacrylamide gels under reducing conditions. The proteins were then transferred to nitrocellulose, the blots were incubated with a monoclonal antibody to apo(a) $(1 \mu \mathrm{g} / \mathrm{ml})$, washed, and then incubated with a goat anti-mouse IgG-horseradish peroxidase conjugate. The antigen-antibody complexes were visualized by use of the Renaissance chemiluminescence kit. Lane 1 , subject 1 ; lane 2 , subject 2; lane 3 , subject 3 ; lane 4 , subject 4 ; lane 5 , subject 5 . The migration position of a $200-\mathrm{kD}$ standard (myosin) is shown.

grade $L p(a)$ from subject 5 above the basal level of control infected cells. In contrast, $\mathrm{Lp}(\mathrm{a})$ from all subjects was internalized and degraded by cells expressing the LDL receptor. Thus, the VLDL receptor demonstrates significant differences in its capacity to internalize and degrade different isoforms of $\mathrm{Lp}(\mathrm{a})$, whereas the LDL receptor does not appear to be as sensitive to the specific isoform of $L p(a)$. The reason for differential recognition of $\mathrm{Lp}(\mathrm{a})$ isoforms by the VLDL receptor is probably due to its specificity for apo(a) and the heterogeneity of apo(a). In contrast to the VLDL receptor, the LDL receptor recognizes apoB100, which remains constant on $\mathrm{Lp}(\mathrm{a})$ and is independent of the apo(a) isoform. It has been demonstrated (51) that the particular apo(a) isoform, and therefore the apo(a) size, can effect the recognition of monoclonal antibodies to $\mathrm{K} 4$ type 2 . Thus, it is conceivable that apo(a) isoform/size may also impact the interaction of the VLDL receptor with apo(a).

Removal of $L p(a)$ antigen from the circulation is delayed in mice deficient in the VLDL receptor. Our in vitro studies have confirmed that the VLDL receptor can bind and mediate cellular catabolism of $\mathrm{Lp}(\mathrm{a})$. The potential significance of these observations can only be tested in an in vivo model. While mice do not express $\mathrm{Lp}(\mathrm{a})$, a high degree of homology exists between mouse and human VLDL receptor (52). To test the hypothesis that the VLDL receptor plays an important role in regulating $L p(a)$ levels, $L p(a)$ was injected into the circulation of control mice and mice genetically deficient in the VLDL receptor, and at selected time intervals blood was collected. After centrifugation, aliquots of plasma were subjected to immunoblot analysis using an antibody specific for apo(a), and the levels of apo(a) were quantified as described in Methods. The results of this study are shown in Fig. 9. In control mice, Lp(a) antigen steadily decreased with time, similar to results described previously (53). Interestingly, the removal of apo(a) was delayed in mice genetically deficient in the VLDL receptor. These results suggest that the VLDL receptor may play an important role in the clearance of $\mathrm{Lp}(\mathrm{a})$ in this mouse model. Conformation of this result will require more detailed studies using several $\mathrm{Lp}(\mathrm{a})$ isoforms. It is clear from the data that clearance of $L p(a)$ is not abolished in mice genetically deficient in the VLDL receptor, and thus a secondary mechanism for the clearance of $\mathrm{Lp}(\mathrm{a})$, possibly involving the LDL receptor, must exist. Therefore, it would be informative to study the clearance of $L p(a)$ in mice lacking both the VLDL receptor and the LDL receptor to determine if it is further delayed or abolished.

The VLDL receptor is expressed in atherosclerotic plaques. The capacity of the VLDL receptor to endocytose $\mathrm{Lp}(\mathrm{a})$ prompted us to examine the expression of this receptor in the vascular wall in atherosclerotic tissue, where Lp(a) antigen has been detected $(8,54)$. Immunohistochemical analysis was performed using a highly specific antibody prepared against a syn-

Table I. Degradation of ${ }^{125}$ I-labeled Lp(a) from Different Subjects by PEA-13 Fibroblasts Infected with Ad-VLDLR or Ad-LDLR

\begin{tabular}{|c|c|c|c|c|}
\hline Subject & $\left.*{ }^{[25} \mathrm{I}-\mathrm{Lp}(\mathrm{a})\right]$ & $\begin{array}{c}{ }^{\sharp} \text { fmoles }{ }^{125} \mathrm{I}-\mathrm{Lp}(\mathrm{a}) \text { degraded/ } \\
10^{5} \text { cells Ad-VLDLR }\end{array}$ & $\begin{array}{c}{ }^{\sharp} \text { fmoles }{ }^{125} \mathrm{I}-\mathrm{Lp}(\mathrm{a}) \text { degraded/ } \\
10^{5} \text { cells Ad-LDLR }\end{array}$ & ${ }^{\S} \mathrm{Apo}(\mathrm{a})$ phenotype \\
\hline & $n M$ & & & \\
\hline \multicolumn{5}{|l|}{ Experiment 1} \\
\hline Subject 1 & 70 & $86 \pm 6$ & $434 \pm 5$ & $\mathrm{~K} 4_{18}(90 \%) / \mathrm{K} 4_{27}(10 \%)$ \\
\hline Subject 2 & 70 & $42 \pm 4$ & $429 \pm 9$ & $\mathrm{~K} 4_{18}(87 \%) / \mathrm{K} 4_{31}(13 \%)$ \\
\hline \multicolumn{5}{|l|}{ Experiment 2} \\
\hline Subject 1 & 70 & $118 \pm 20$ & $489 \pm 7$ & $\mathrm{~K} 4_{18}(90 \%) / \mathrm{K} 4_{27}(10 \%)$ \\
\hline Subject 3 & 70 & $40 \pm 11$ & $459 \pm 4$ & $\mathrm{~K} 4_{17}(100 \%)$ \\
\hline Subject 4 & 29 & $22 \pm 2$ & $327 \pm 5$ & $\mathrm{~K} 4_{23}(52 \%) / \mathrm{K} 4_{22}(48 \%)$ \\
\hline Subject 5 & 70 & $0 \pm 4$ & $341 \pm 35$ & $\mathrm{~K} 4_{23}(85 \%) / \mathrm{K} 4_{27}(15 \%)$ \\
\hline
\end{tabular}

*Concentration of ${ }^{125} \mathrm{I}$-labeled $\mathrm{Lp}(\mathrm{a})$ added to cells. In the case of subject 4, lower concentrations of Lp(a) were used since the recovery of $\mathrm{Lp}(\mathrm{a})$ from this subject was lower, and precluded the use of higher concentrations. *Values were generated by subtraction of basal levels of degradation observed in PEA-13 fibroblasts infected with Ad-LacZ. ${ }^{\S} \mathrm{Apo}$ (a) phenotypes were determined as described (27). nd, not determined. 


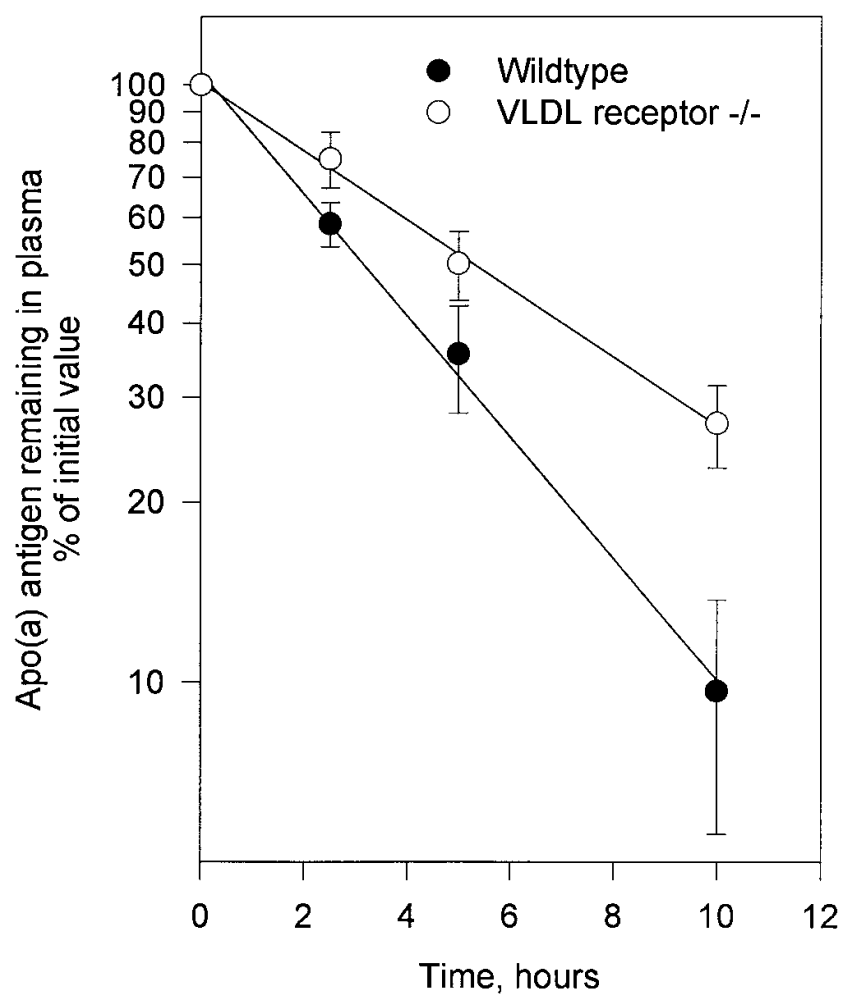

Figure 9. VLDL receptor-deficient mice demonstrate delayed clearance of $\mathrm{Lp}$ (a) from the circulation. Wild-type mice (closed circles) $(n=5)$ and VLDL receptor-deficient mice (open circles) $(n=4)$ were injected with $100 \mu \mathrm{g} \mathrm{Lp}(\mathrm{a})$ from subject 1 . Blood was drawn at indicated times after injection, and an aliquot $(0.1 \mu \mathrm{L})$ was subjected to SDS-PAGE under reducing conditions on $4 \%$ polyacrylamide gels. After transfer to nitrocellulose, the blots were incubated with a monoclonal antibody against apo(a) $(1 \mu \mathrm{g} / \mathrm{ml})$, and apo(a) antigen was quantified as described in Methods. The initial time point, taken at $2 \mathrm{~min}$, was considered to represent $100 \%$ antigen in the circulation.

thetic peptide representing the carboxy-terminal portion of the VLDL receptor. Strong staining for VLDL receptor antigen was detected in endothelial cells of normal vessels and atherosclerotic arteries, consistent with previous data $(29,55,56)$. Double staining was performed to assess precise colocalization of the VLDL receptor antigen and the antigen marker for either macrophages or smooth muscle cells. Examination of coronary atherectomy specimens revealed that VLDL receptor antigen was present in the majority of plaque KP-1-positive macrophages and foam cells (Fig. 10A). The majority of $\alpha$-actin positive smooth muscle cells, however, did not stain positively for the VLDL receptor antigen, although a small percentage of $\alpha$-actin positive cells did stain for the VLDL receptor antigen in the cap region of the atherosclerotic plaque (Fig. $10 \mathrm{~B}$ ). In addition, VLDL receptor staining was present in extracellular matrix-rich areas of the plaque (Fig. $10 B$ ), possibly representing receptor that is shed from the cell surface after proteolytic cleavage. The VLDL receptor is known to bind to the extracellular matrix component thrombospondin (57), which may account for its localization in matrix. No staining was observed when the VLDL receptor antibody was preincubated with the synthetic peptide to which the antibody was made before staining.

\section{Discussion}

The physiological function of $\mathrm{Lp}(\mathrm{a})$ is not fully understood. Elevated plasma levels of this lipoprotein, however, are associated with an increased risk for coronary and carotid artery disease $(1,2)$, and $\mathrm{Lp}(\mathrm{a})$ antigen has been detected in plaque tissue in atherosclerotic cerebral vessels (58), and in atherosclerotic, but not in nonatherosclerotic, coronary vessels $(8$, 54). Despite several hypotheses regarding the roles of $L p(a)$ in atherosclerosis, the mechanism of $\mathrm{Lp}(\mathrm{a})$ atherogenicity has not been elucidated, but likely involves both its ability to influence plasminogen activation as well as its atherogenic potential as a lipoprotein particle after receptor-mediated uptake. The mechanisms responsible for the catabolism of $\mathrm{Lp}$ (a) have been investigated $(14,15)$, and the studies reveal that while the LDL receptor may contribute to $\mathrm{Lp}$ (a) catabolism, it is clear that another receptor must play a major role in the cellular uptake of $\mathrm{Lp}(\mathrm{a})$ in the vessel wall.

The results of this study indicate that the VLDL receptor can bind to and mediate the cellular catabolism of $\mathrm{Lp}(\mathrm{a})$, and that the VLDL receptor may play an important role in $\mathrm{Lp}(\mathrm{a})$ catabolism. This conclusion is supported by several independent lines of evidence. First, ${ }^{125}$ I-labeled Lp(a) is internalized and degraded by fibroblasts in which the human VLDL receptor cDNA was introduced using adenovirus-mediated gene transfer, but not by control fibroblasts that lack this receptor. Second, the cellular uptake and degradation of ${ }^{125}$ I-labeled $\mathrm{Lp}(\mathrm{a})$ in fibroblasts expressing the VLDL receptor is blocked by specific antibodies against the VLDL receptor. Third, ${ }^{125} \mathrm{I}$ Lp(a) binds to the purified VLDL receptor immobilized on nitrocellulose. The specificity of this interaction was demonstrated when RAP, an inhibitor of VLDL receptor function, prevented ligand binding. Finally, removal of $L p(a)$ injected into the mouse circulation was delayed in mice genetically deficient in the VLDL receptor when compared with control mice. Together, these experiments provide compelling evidence indicating that the VLDL receptor can mediate the cellular catabolism of $\operatorname{Lp}(\mathrm{a})$, and that this receptor likely plays an important role in $\mathrm{Lp}$ (a) catabolism in vivo.

Currently, the physiological role of the VLDL receptor is not completely understood. The observation that VLDL receptor mRNA is highly expressed in skeletal muscle, heart, and adipose tissue, but not liver $(59,60)$, has led to the hypothesis that this receptor may facilitate peripheral uptake of triglyceride-rich lipoproteins. Mice in which the VLDL receptor gene has been deleted, however, displayed normal levels of cholesterol, triacylglycerol, and lipoproteins in their plasma, suggesting that the VLDL receptor is not required for VLDL clearance from plasma (42). Indirect immunofluorescence on murine and bovine tissue (55) and in situ hybridization studies on human tissue (56) revealed that the VLDL receptor is preferentially expressed on the endothelium of nonfenestrated capillaries. This observation, coupled with the fact that the VLDL receptor-deficient mice display a decrease in body weight, body mass index, and adipose tissue mass, suggests that the VLDL receptor may play an important role in the delivery of VLDL or other bloodborne nutrients into tissues. Our studies, demonstrating that $\mathrm{Lp}$ (a) clearance is delayed in mice deficient in the VLDL receptor, highlight the potential significance of this receptor in $\mathrm{Lp}(\mathrm{a})$ catabolism. While mice do not express Lp(a), a high degree of homology exists between mouse and human VLDL receptor (52), and therefore, 


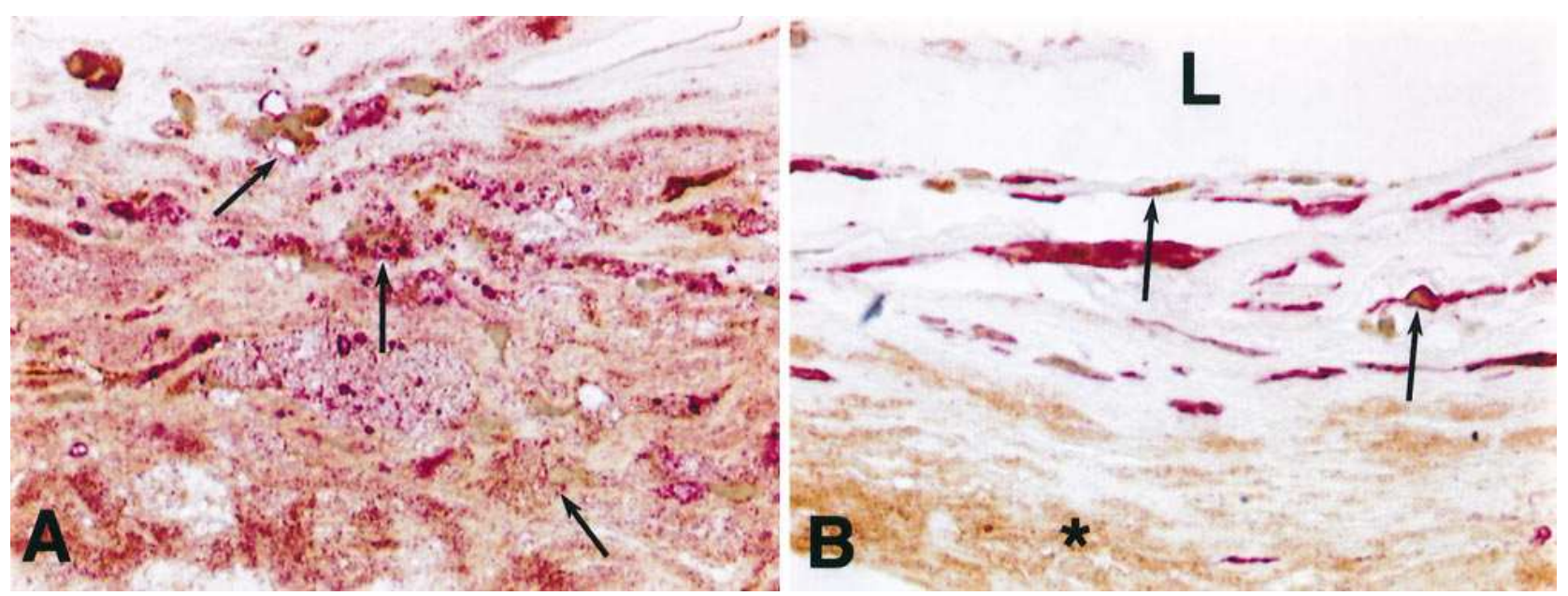

Figure 10. Photomicrographs of double-stained human coronary endarterectomy specimens. (A) Detection of VLDL receptor antigen (brown) and macrophage marker, CD-68 (red), deep in the atherosclerotic plaque. Arrows denote macrophages that are doubly stained for the VLDL receptor antigen and macrophage marker CD-68 antigen. $(B)$ Detection of VLDL receptor antigen (brown) and smooth muscle cell marker, $\alpha$-actin $(r e d)$ in the fibrous cap near the lumen $(L)$. Arrows denote doubly stained cells. The asterisk denotes extracellular matrix staining for the VLDL receptor. ( $A$ and $B$, original $400 \times$ ).

the mouse is an excellent model for these studies. The organ(s) responsible for the clearance of $\operatorname{Lp}(\mathrm{a})$ have yet to be identified, but given that the VLDL receptor is expressed in the endothelium, it seems likely that the VLDL receptor may target $\mathrm{Lp}(\mathrm{a})$ to the vascular wall. Studies to test this possibility are currently underway.

Catabolism of $\mathrm{Lp}(\mathrm{a})$ is effectively prevented by a 50 -fold molar excess of apo(a), indicating that a unique determinant exists on $\mathrm{Lp}(\mathrm{a})$ that is not present on LDL recognized by the VLDL receptor. Competition experiments revealed that while LDL is an effective competitor of $\mathrm{Lp}(\mathrm{a})$ catabolism mediated by the LDL receptor, it is not an effective inhibitor of $\mathrm{Lp}(\mathrm{a})$ catabolism mediated by the VLDL receptor. Thus, under physiological conditions where normal LDL levels are significantly higher than those of $\operatorname{Lp}(a)$, it is unlikely that the LDL receptor is involved in the catabolism of $\mathrm{Lp}(\mathrm{a})$. In contrast, normal levels of LDL are likely to have little impact on catabolism of Lp(a) mediated by the VLDL receptor. The VLDL receptor differentially recognizes specific isoforms of $\mathrm{Lp}(\mathrm{a})$. While the significance of this fact is not known, it would be of interest to determine if the ability of $\operatorname{Lp}(\mathrm{a})$ to bind to the VLDL receptor correlates with its atherogenicity. The regions on apo(a) responsible for VLDL receptor recognition remain to be identified.

Our finding that VLDL receptor expression is induced in macrophages within atherosclerotic plaques raises the possibility that the VLDL receptor may also play a pathophysiological role by mediating Lp(a) endocytosis, thus facilitating lipid delivery to macrophages at lesion sites. Excessive accumulation of lipids in macrophages leading to foam cell formation is a feature of the fatty streak (61). Cellular uptake of $L p(a)$, mediated by the VLDL receptor, may contribute to foam cell formation. This possibility is strengthened by the observations that while the VLDL receptor gene has two copies of sterol regulatory element 1-like sequences (62), they are inactive in vivo, and thus expression of the VLDL receptor is not effected by cellular cholesterol levels $(33,48,62)$. Chinese hamster ovary cells that overexpress the VLDL receptor accumulate lipid and are converted into foam cells when incubated with rabbit $\beta$-VLDL (48), providing evidence that the VLDL receptor can contribute to foam cell formation.

VLDL receptor mRNA has been detected in cultures of rabbit resident alveolar macrophages and the THP-1 human monocytic leukemia cell line (48). In contrast, VLDL receptor mRNA (59) and antigen (F. Battey and D.K. Strickland, unpublished observations) are not detected in human monocyte-derived macrophages in culture. These observations are consistent with the findings that while $\mathrm{Lp}$ (a) binds to monocyte-derived macrophages in culture, it is not efficiently internalized and degraded by these cells $(63,64)$. The high-level expression of the VLDL receptor noted in macrophages in atherosclerotic plaques indicates that VLDL receptor expression is induced in these cells. Several studies indicate that expression of the VLDL receptor gene is regulated. Increased expression of VLDL receptor mRNA was observed when 3T3-L1 cells were differentiated into adipocytes (60). Furthermore, the VLDL receptor gene appears to be regulated by estrogen (65), and expression of the VLDL receptor in skeletal muscle can be regulated by thyroid hormone (66). Finally, administration of human granulocyte-macrophage colony-stimulating factor into rabbits induced a 2.6-fold increase in VLDL receptor mRNA in muscle (67). All of these studies confirm that expression of the VLDL receptor gene is highly regulated. Factors that might induce expression of the VLDL receptor in macrophages in atherosclerotic lesions remain to be identified. Interestingly, Bottalico et al. (16) have observed that cholesterol loading of macrophages leads to an enhancement of $\mathrm{Lp}(\mathrm{a})$ internalization and degradation via induction of a specific receptor. The receptor responsible for this effect has not yet been identified. Since RAP did not appear to inhibit the degradation (16), however, it may not be the VLDL receptor.

In summary, we have identified a receptor that is capable of mediating the cellular catabolism of $\mathrm{Lp}(\mathrm{a})$, most likely via interaction with apo(a). The widespread distribution and ex- 
pression of the VLDL receptor in vascular cells and in macrophages in atherosclerotic lesions suggests that this receptor may target $\mathrm{Lp}(\mathrm{a})$ to the vascular endothelium and to macrophages present in atherosclerotic lesions. Excessive uptake of $\mathrm{Lp}$ (a) by lesion macrophages may lead to lipid accumulation by these cells, and may account in part for the atherogenicity of this lipoprotein.

\section{Acknowledgments}

We are indebted to Celina Edelstein for providing us with the details of a new method for the purification of apo(a) before its publication, and to Keith McCray for providing us with a copy of his manuscript before publication. We thank J. Herz (Dallas, TX) for generously providing the MEF and PEA-13 fibroblasts that were used in this study. The authors appreciate the assistance of Steingrimur Stefansson in experiments using F9 cells, Sue Robinson for antibody production and purification, and for invaluable assistance in the clearance experiments, and Evan Behre for RAP production.

This work was supported by Grants HL50787, GM42581 (to D.K. Strickland) and HL54469 (to P.C. Harpel) from the National Institutes of Health.

\section{References}

1. Schaefer, E.J., S. Lamno-Fava, J.L. Jenner, J.R. McNamara, J.M. Ordovas, C.E. Davis, J.M. Abolafia, K. Lippel, and R.I. Levy. 1994. Lipoprotein(a) levels and risk of coronary heart disease in men. JAMA. 271:999-1003.

2. Utermann, G. 1990. The mysteries of Lp(a) lipoprotein. Science (Wash. DC). 246:904-910

3. Bostom, A.G., L.A. Cupples, J.L. Jenner, J.M. Ordovas, L.J. Seman, P.W.F. Wilson, E.J. Schaefer, and W.P. Castelli. 1996. Elevated plasma lipoprotein(a) and coronary heart disease in men aged 55 years and younger. JAMA. 276:544-548.

4. McLean, J.W., J.E. Tomlinson, W. Kuang, D.L. Eaton, E.Y. Chen, G.M. Fless, A.M. Scanu, and R.M. Lawn. 1987. cDNA sequence of human apolipoprotein(a) is homologous to plasminogen. Nature (Lond.). 330:132-137.

5. Lackner, C., J.C. Cohen, and H.H. Hobbs. 1993. Molecular definition of the extreme size polymorphism in apolipoprotein(a). Hum. Mol. Genet. 2:933940.

6. Gaw, A., and H.H. Hobbs. 1994. Molecular genetics of lipoprotein(a): new pieces to the puzzle. Curr. Opin. Lipidol. 5:149-155.

7. Miles, L.A., G.M. Fless, E.G. Levine, A.M. Scanu, and E.F. Plow. 1989. A potential basis for the thrombotic risks associated with lipoprotein(a). Nature (Lond.). 339:301-303.

8. Hajjar, K.A., D. Gavish, J.L. Breslow, and R.L. Nachman. 1989. Lipoprotein(a) modulation of endothelial cell surface fibrinolysis and its potential role in atherosclerosis. Nature (Lond.). 339:303-305.

9. Kojima, S., P.C. Harpel, and D.B. Rifkin. 1991. Lipoprotein(a) inhibits the generation of transforming growth factor- $\exists$ : an endogenous inhibitor of smooth muscle cell migration. J. Cell Biol. 113:1439-1445.

10. Lawn, R.M., D.P. Wade, R.E. Hammer, G. Chiesa, J.G. Verstuyft, and E.M. Rubin. 1992. Atherogenesis in transgenic mice expressing human apolipoprotein(a). Nature (Lond.). 360:670-672.

11. Grainger, D.J., P.R. Kemp, A.C. Lui, R.M. Lawn, and J.C. Metcalfe. 1994. Activation of transforming growth factor- $\exists$ is inhibited in transgenic apolipoprotein(a) mice. Nature (Lond.). 370:460-462.

12. Brown, M.S., and J.L. Goldstein. 1987. Plasma lipoproteins: teaching old dogmas new tricks. Nature (Lond.). 330:113-114.

13. Brown, M.S., and J.L. Goldstein. 1986. A receptor-mediated pathway for cholesterol homeostasis. Science (Wash. DC). 232:34-47.

14. Hofmann, S.L., D.L. Eaton, M.S. Brown, W.J. McConathy, J.L. Goldstein, and R.E. Hammer. 1990. Overexpression of human low density lipoprotein receptors leads to accelerated catabolism of $\mathrm{Lp}$ (a) lipoprotein in transgenic mice. J. Clin. Invest. 85:1542-1547.

15. Rader, D.J., W.A. Mann, W. Cain, H. Kraft, D. Usher, L.A. Zech, J.M. Hoeg, J. Davignon, P. Lupien, M. Grossman, et al. 1995. The low density lipoprotein receptor is not required for normal catabolism of $\mathrm{Lp}(\mathrm{a})$ in humans. $J$. Clin. Invest. 95:1403-1408.

16. Bottalico, L.A., G.A. Keesler, G.M. Fless, and I. Tabas. 1993. Cholesterol loading of macrophages leads to marked enhancement of native lipoprotein(a) and apoprotein(a) internalization and degradation. J. Biol. Chem. 268: 8569-8573.

17. Marz, W., A. Beckmann, H. Scharnagl, R. Siekmeier, U. Mondorf, I. Held, W. Schneider, K.T. Preissner, L.K. Curtiss, and W. Gross. 1993. Hetero- geneous lipoprotein (a) size isoforms differ by their interaction with the low density lipoprotein receptor and the low density lipoprotein receptor-related protein/alpha 2-macroglobulin receptor. FEBS Lett. 325:271-275.

18. Strickland, D.K., M.Z. Kounnas, and W.S. Argraves. 1995. LDL receptor-related protein: A multiligand receptor for lipoprotein and proteinase catabolism. FASEB J. 9:890-898.

19. Krieger, M., and J. Herz. 1994. Structures and functions of multiligand lipoprotein receptors: macrophage scavenger receptors and LDL receptorrelated protein (LRP). Annu. Rev. Biochem. 63:601-637.

20. Moestrup, S.K. 1994. The $\forall_{2}$-macroglobulin receptor and epithelial glycoprotein-330: two giant receptors mediating endocytosis of multiple ligands. Biochem. Biophys. Acta. 1197:197-213.

21. Williams, S.E., J.D. Ashcom, W.S. Argraves, and D.K. Strickland. 1992. A novel mechanism for controlling the activity of $\forall_{2}$-macroglobulin receptor/ low density lipoprotein receptor-related protein. Multiple regulatory sites for 39-kDa receptor-associated protein. J. Biol. Chem. 267:9035-9040.

22. Kounnas, M.Z., W.S. Argraves, and D.K. Strickland. 1992. The 39-kDa receptor-associated protein interacts with two members of the low density lipoprotein receptor family, $\forall_{2}$-macroglobulin receptor and glycoprotein 330 . $J$. Biol. Chem. 267:21162-21166.

23. Orlando, R.A., D. Kerjaschki, H. Kurihara, D. Biemesderfer, and M.G. Farquhar. 1992. gp330 Associates with a 44-kDa protein in the rat kidney to form the Heymann nephritis antigenic complex. Proc. Natl. Acad. Sci. USA. 89: 6698-6702.

24. Battey, F., M.E. Gåfvels, D.J. Fitzgerald, W.S. Argraves, D.A. Chappell, J.F. Strauss III, and D.K. Strickland. 1994. The $39 \mathrm{kDa}$ receptor associated protein regulates ligand binding by the very low density lipoprotein receptor. $J$. Biol. Chem. 269:23268-23273.

25. Medh, J.D., G.L. Fry, S.L. Bowen, M.W. Pladet, D.K. Strickland, and D.A. Chappell. 1995. The $39 \mathrm{kDa}$ receptor-associated protein modulates lipoprotein catabolism by binding to LDL receptors. J. Biol. Chem. 270:536-540.

26. Harpel, P.C., B.R. Gordon, and T.S. Parker. 1989. Plasmin catalyzes binding of lipoprotein(a) to immobilized fibrinogen and fibrin. Proc. Natl. Acad. Sci. USA. 86:3847-3851.

27. Marcovina, S.M., H.H. Hobbs, and J.J. Albers. 1996. Relation between number of apolipoprotein(a) kringle 4 repeats and mobility of isoforms in agarose gel: basis for a standardized isoform nomenclature. Clin. Chem. 42:436439 .

28. Edelstein, C., M. Mandala, and A.M. Scanu. 1995. Determinants of lipoprotein(a) assembly: a study of wild-type and mutant apolipoprotein(a) phenotypes isolated from human and rhesus monkey lipoprotein(a) under mild reductive conditions. Biochemistry. 34:16483-16492.

29. Argraves, K.M., F.D. Battey, C.D. MacCalman, K.R. McCrae, M. Gåfvels, K.F. Kozarsky, D.A. Chappell, J.F. Strauss, and D.K. Strickland. 1995. The very low density lipoprotein receptor mediates the cellular catabolism of lipoprotein lipase and urokinase-plasminogen activator inhibitor type I complexes. J. Biol. Chem. 270:26550-26557.

30. Bilheimer, D.W., S. Eisenberg, and R.I. Levy. 1972. The metabolism of very low density lipoproteins. I. Preliminary in vitro and in vivo observations. Biochem. Biophys. Acta. 260:212-221.

31. Willnow, T.E., and J. Herz. 1994. Genetic deficiency in low density lipoprotein receptor-related protein confers cellular resistance to Pseudomonas exotoxin A: evidence that this protein is required for uptake and degradation of multiple ligands. J. Cell Sci. 107:719-726.

32. Stefansson, S., D.A. Chappell, K.M. Argraves, D.K. Strickland, and W.S. Argraves. 1995. Glycoprotein 330/low density lipoprotein receptor-related protein-2 mediates endocytosis of low density lipoproteins via interaction with apolipoprotein B100. J. Biol. Chem. 270:19417-19421.

33. Wittmaack, F.M., M. Gåfvels, M. Bronner, H. Matsuo, K. McCrae, J. Tomaszewski, S.L. Robinson, D.K. Strickland, and J.F.I. Strauss. 1995. Localization and regulation of the human VLDL/ApoE receptor: trophoblast expression predicts a role for the receptor in placental lipid transport. Endocrinology. 136:340-348.

34. Kounnas, M.Z., R.E. Morris, M.R. Thompson, D.J. Fitzgerald, D.K Strickland, and C.B. Saelinger. 1992. The $\forall_{2}$-macroglobulin receptor/low density lipoprotein receptor-related protein binds and internalizes Pseudomonas exotoxin A. J. Biol. Chem. 267:12420-12423.

35. Milne, R.W., R.J. Theolis, R.B. Verdery, and Y.L. Marcel. 1983. Characterization of monoclonal antibodies against human low density lipoprotein. Arteriosclerosis. 3:23-30.

36. Harpel, P.C. 1981. $\forall_{2}$-Plasmin inhibitor and $\forall_{2}$-macroglobulin-plasmin complexes in plasma. Quantitation by an enzyme-linked differential antibody immunosorbent assay. J. Clin. Invest. 68:46-55.

37. Voller, A., D.E. Bidwell, and A. Bartlett. 1976. Microplate enzyme immunoassays for the immunodiagnosis of virus infections. In Manual of Clinical Immunology. N.R. Rose and H. Freedman, editors. American Society of Microbiology, Washington, D.C. 506-512.

38. Kozarsky, K.F., K. Jooss, M. Donahae, J.F. Strauss, and J.M. Wilson. 1996. Effective and persistent treatment of familial hypercholesterolaemia in the mouse model using adenovirus-mediated transfer of the VLDL receptor gene. Nat. Genet. 13:54-62.

39. Forsayeth, J.R., and P.D. Garcia. 1994. Adenovirus-mediated transfec- 
tion of cultured cells. Biotechniques. 17:354-359.

40. Chappell, D.A., G.L. Fry, M.A. Waknitz, P.-H. Iverius, S.E. Williams, and D.K. Strickland. 1992. The low density lipoprotein receptor-related protein $/ \forall_{2}$-macroglobulin receptor binds and mediates catabolism of bovine milk lipoprotein lipase. J. Biol. Chem. 267:25764-25767.

41. Bradford, M.M. 1976. A rapid and sensitive method for the quantitation of microgram quantities of protein utilizing the principal of protein-dye binding. Anal. Biochem. 72:248-255.

42. Frykman, P.K., M.S. Brown, T. Yamamoto, J.L. Goldstein, and J. Herz. 1995. Normal plasma lipoproteins and fertility in gene-targeted mice homozygous for a disruption in the gene encoding very low density lipoprotein receptor. Proc. Natl. Acad. Sci. USA. 92:8453-8457.

43. Becker, T.C., R.J. Noel, W.S. Coats, A.M. Gomex-Foix, T. Alam, R.D. Gerard, and C.B. Newgard. 1994. Use of recombinant adenovirus for metabolic engineering of mammalian cells. Methods Cell Biol. 43:161-189.

44. Simonsen, A.C.W., C.W. Heegard, L. Rasmussen,K., L. Ellgaard, L. Kjoller, A. Christensen, M. Etzerodt, and P.A. Andreasen. 1994. Very low density lipoprotein receptor from mammary gland and mammary epithelial cell lines binds and mediates endocytosis of $\mathrm{Mr} 40000$ receptor associated protein. FEBS Lett. 354:279-283.

45. Kounnas, M.Z., R.D. Moir, G.W. Rebeck, A.I. Bush, W.S. Argraves, R.E. Tanzi, B.T. Hyman, and D.K. Strickland. 1995. LDL receptor-related protein, a multifunctional apoE receptor, binds secreted $\exists$-amyloid precursor protein and mediates its degradation. Cell. 82:331-340.

46. Heegaard, C.W., A.C.W. Simonsen, K. Oka, L. Kjoller, A. Christensen, B. Madsen, L. Ellgaard, L. Chan, and P.A. Andreasen. 1995. Very low density lipoprotein receptor binds and mediates endocytosis of urokinase-type plasminogen activator-type-1 plasminogen activator inhibitor complex. J. Biol. Chem. 270:20855-20861.

47. Takahashi, S., Y. Kawarabayasi, T. Nakai, J. Sakai, and T. Yamamoto. 1992. Rabbit very low density lipoprotein receptor: a low density lipoprotein receptor-like protein with distinct ligand specificity. Proc. Natl. Acad. Sci. USA. 89:9252-9256.

48. Suzuki, J., S. Takahashi, K. Oida, A. Shimada, M. Kohno, T. Tamai, S. Miyabo, T. Yamamoto, and T. Nakai. 1995. Lipid accumulation and foam cell formation in chinese hamster ovary cells overexpressing very low density lipoprotein receptor. Biochem. Biophys. Res. Commun. 206:835-842.

49. Utermann, G., H.J. Menzel, H.G. Kraft, H.C. Duba, H.G. Kemmler, and C. Seitz. 1987. Lp(a) glycoprotein phenotypes: inheritance and correlation to Lp(a)-lipoprotein concentrations in plasma. J. Clin. Invest. 80:458-465.

50. Lackner, C., E. Boerwinkle, C.C. Leffert, T. Rahmig, and H.H. Hobbs. 1991. Molecular basis of apolipoprotein(a) isoform size heterogeneity as revealed by pulsed-field gel electrophoresis. J. Clin. Invest. 87:563-567.

51. Marcovina, S.M., J.J. Albers, B. Gabel, M.L. Koschinsky, and V.P. Gaur. 1995. Effect of the number of apolipoprotein(a) kringle 4 domains on immunochemical measurements of lipoprotein(a). Clin. Chem. 41:246-255.

52. Gåfvels, M.E., L.G. Paavola, C.O. Boyd, P.M. Nolan, F. Wittmaack, J. Chawla, M.A. Lazar, J. Bucan, B. Angelin, and J.F. Strauss III. 1994. Cloning of a complementary deoxyribonucleic acid encoding the murine homolog of the very low density lipoprotein/apolipoprotein-E receptor: expression pattern and assignment of the gene to mouse chromosome 19. Endocrinology. 135:387-394.

53. Mooser, V., M.C. Seabra, M. Abedin, K. Landschulz, S. Marcovina, and H.H. Hobbs. 1996. Apolipoprotein(a) kringle 4-containing fragments in human urine. Relationship to plasma levels of lipoprotein(a). J. Clin. Invest. 97:858864.

54. Rath, M., A. Niendorf, T. Reblin, M. Dietel, H. Krebber, and U. Beisiegel. 1989. Detection and quantitation of lipoprotein(a) in the arterial wall of 107 cororary bypass patients. Arteriosclerosis. 9:579-592.

55. Wyne, K.L., R.K. Pathak, M.C. Seabra, and H.H. Hobbs. 1996. Expression of the VLDL receptor in endothelial cells. Arterioscler. Thromb. Vasc. Biol. 16:407-415.

56. Multhaupt, H.A.B., M.E. Gåfvels, K. Kariko, H. Jin, C. Arenas-Elliott, B.I. Goldman, J.F.I. Strauss, B. Angelin, M.J. Warhol, and K.R. McCrae. 1996 Expression of very low density lipoprotein receptor in the vascular wall: analysis of human tissues by in situ hybridization and immunohistochemistry. Am J. Pathol. 148:1985-1997.

57. Mikhailenko, I., D. Krylov, K.M. Argraves, D.D. Roberts, G. Liau, and D.K. Strickland. 1997. Cellular internalization and degradation of thrombospondin-1 is mediated by the amino-terminal heparin binding domain (HBD) High affinity interaction of dimeric HBD with the low density lipoprotein receptor-related protein. J. Biol. Chem. 272:6784-6791.

58. Jamiseon, D.G., D.C. Usher, D.J. Rader, and E. Lavi. 1995. Apolipoprotein(a) deposition in atherosclerotic plaques of cerebral vessels. Am. J. Pathol 147:1567-1574.

59. Webb, J.C., D.D. Patel, M.D. Jones, B.L. Knight, and A.K. Soutar. 1994 Characterization and tissue-specific expression of the human very low density lipoprotein (VLDL) receptor. Hum. Mol. Genet. 3:531-537.

60. Gåfvels, M.E., M. Caird, D. Britt, C.L. Jackson, D. Patterson, and J.F. Strauss,III. 1993. Cloning of a cDNA encoding a putative human very low density lipoprotein/apolipoprotein $\mathrm{E}$ receptor and assignment of the gene to chromosome 9pter-p23. Somatic Cell Mol. Genet. 19:557-569.

61. Ross, R. 1993. The pathogeneis of atherosclerosis: a perspective for the 1990s. Nature (Lond.). 362:801-809.

62. Sakai, J., A. Hoshino, S. Takahashi, Y. Miura, H. Ishii, H. Suzuki, Y. Kawarabayasi, and T. Yamamoto. 1994. Structure, chromosome location, and expression of the human very low density lipoprotein receptor gene. J. Biol. Chem. 269:2173-2182.

63. Zioncheck, T.F., L.M. Powell, G.C. Rice, D.L. Eaton, and R.M. Lawn. 1991. Interaction of recombinant apolipoprotein(a) and lipoprotein (a) with macrophages. J. Clin. Invest. 87:767-771.

64. Snyder, M.L., D. Polacek, A.M. Scanu, and G.M. Fless. 1992. Comparative binding and degradation of lipoprotein(a) and low density lipoprotein by human monocyte-derived macrophages. J. Biol. Chem. 267:339-346.

65. Masuzaki, H., H. Jingami, T. Yamamoto, and K. Nakao. 1994. Effects of estradiol on very low density lipoprotein receptor mRNA levels in rabbit heart. FEBS Lett. 347:211-214.

66. Jokinen, E.V., K.T. Landschulz, K.L. Wyne, Y.K. Ko, P.K. Frykman, and H.H. Hobbs. 1994. Regualtion of the very low density lipoprotein receptor by thyroid hormone in rat skeletal muscle. J. Biol. Chem. 269:26411-26418.

67. Ishibashi, T., K. Yokoyama, J. Shindo, Y. Hamazaki, Y. Endo, T. Sato, S. Takahashi, Y. Kawarabayasi, M. Shiomi, T. Yamamoto, and Y. Maruyama. 1994. Potent cholesterol-lowering effect by human granulocyte-macrophage colony-stimulating factor in rabbits: possible implications of enhancement of macrophage functions and an increase in mRNA for VLDL receptor. Arterioscler. Thromb. 14:1534-1541. 